\title{
Paracrine and endocrine actions of interferon tau (IFNT)
}

\author{
Thomas R Hansen ${ }^{1}$, Leticia D P Sinedino ${ }^{1}$ and Thomas E Spencer ${ }^{2}$ \\ ${ }^{1}$ Animal Reproduction and Biotechnology Laboratory, Department of Biomedical Sciences, College of Veterinary \\ Medicine and Biomedical Sciences, Colorado State University, Fort Collins, Colorado, USA and ${ }^{2}$ Division of Animal \\ Sciences and Department of Obstetrics, Gynecology and Women's Health, University of Missouri, Columbia, \\ Missouri, USA
}

Correspondence should be addressed to TR Hansen or T E Spencer; Email: thomas.hansen@colostate.edu or spencerte@missouri.edu

\begin{abstract}
This review focuses on the paracrine and endocrine actions of interferon tau (IFNT) during pregnancy recognition and establishment in ruminants. Pregnancy recognition involves the suppression of the endometrial luteolytic mechanism by the conceptus to maintain progesterone production by the corpus luteum (CL). The paracrine antiluteolytic effects of conceptus-derived IFNT inhibit upregulation of oxytocin receptors in the endometrial epithelia of the uterus, thereby preventing the production of luteolytic prostaglandin F2 alpha (PGF2 $\alpha$ ) pulses. In the endometrium, IFNT induces or upregulates a large number of classical IFN-stimulated genes (ISGs) and regulates expression of many other genes in a cell-specific manner that are likely important for conceptus elongation, implantation and establishment of pregnancy. Further, IFNT has endocrine effects on extrauterine cells and tissues. In sheep, IFNT induces luteal resistance to PGF2 $\alpha$, thereby ensuring survival of the CL for maintenance of pregnancy. The ISGs induced in circulating peripheral blood mononuclear cells by IFNT may also be useful as an indicator of pregnancy status in cattle. An increased knowledge of IFNT and ISGs is important to improve the reproductive efficiency in ruminants.

Reproduction (2017) $\mathbf{1 5 4}$ F45-F59
\end{abstract}

\section{Introduction}

In domestic ruminants, establishment of pregnancy requires pregnancy recognition signaling followed by implantation and placentation (Guillomot et al. 1993, Guillomot 1995, Spencer et al. 2004b, 2007, 2008). On days $4-6$ post mating, the morula-stage embryo enters the uterus and then forms a blastocyst with an inner cell mass and a blastocoele or central cavity surrounded by a monolayer of trophectoderm cells. Following hatching from the zona pellucida, the blastocyst develops into an ovoid and then tubular conceptus that begins to elongate on day 12 (sheep) or day 15 (cattle) into a filamentous form that eventually occupies the entire length of the uterine horn. Elongation of the conceptus is critical for the production of interferon tau (IFNT), the pregnancy recognition signal, and implantation (Farin et al. 1989, Guillomot et al. 1990, Gray et al. 2002). Proliferation of mononuclear trophoblast cells (Wang et al. 2009) primarily drives exponential increases in length of the trophectoderm during conceptus elongation (Wales \& Cuneo 1989).

Although blastocysts can be developed entirely in vitro, the efficiency and resulting quality is markedly lower than that in vivo (Hasler et al. 1995). Indeed, a blastocyst must be transferred into the uterus for it to develop into an elongated filamentous type conceptus (Heyman et al. 1984, Flechon etal. 1986, Maddox-Hyttell et al. 2003). Indeed, the epithelia of the uterus produce embryotrophic factors in response to progestreone that stimulate blastocyst growth and conceptus elongation (Bazer et al. 2011, Lonergan et al. 2015, Spencer \& Hansen 2015, Spencer et al. 2016).

\section{Pregnancy recognition: paracrine antiluteolytic effects of IFNT}

Maternal recognition of pregnancy can be defined as the physiological process whereby the conceptus signals its presence to the maternal system and prolongs the lifespan of the ovarian corpus luteum (CL) (Bazer et al. 1991). This process in ruminants requires that the conceptus elongate to produce sufficient IFNT to signal pregnancy recognition and suppress development of the endometrial luteolytic mechanism (Spencer et al. 1996b, Roberts et al. 1999, 2008b, Spencer \& Bazer 2002). The antiluteolytic effects of IFNT on the endometrium maintain $\mathrm{CL}$ function and thus secretion of progesterone, which is essential for conceptus growth and development throughout pregnancy. 


\section{Endometrial luteolytic mechanism}

Ruminants (sheep, cattle, goats) are spontaneous ovulators that have uterine-dependent oestrus cycles, because the endometrium is the source of the luteolysin, prostaglandin F2 alpha (PGF2 $\alpha$ ) (Wathes \& Lamming 1995, McCracken et al. 1999, Spencer \& Bazer 2002). At the end of the oestrus cycle, the endometrium produces and releases luteolytic pulses of PGF2 $\alpha$ in response to oxytocin that cause functional and structural regression of the $\mathrm{CL}$, a process termed luteolysis. In sheep, the source of luteolytic PGF2 $\alpha$ pulses is the endometrial luminal epithelium (LE) (Gray et al. 2000), because those cells express the oxytocin receptor (OXTR) (Wathes \& Lamming 1995) and prostaglandin-endoperoxide synthase 2 (PTGS2), an essential enzyme in PG synthesis (Charpigny et al. 1997, Simmons et al. 2010). Both OXTR and PTGS2 are required for the synthesis and secretion of luteolytic PGF2 $\alpha$.

As summarized in Fig. 1 for sheep, the luteolytic mechanism of the endometrial LE involves progesterone, oestrogen and oxytocin and their respective receptors (McCracken et al. 1984, Spencer et al. 1996b, Spencer \& Bazer 2002). At oestrus (day 0), oestrogen from ovarian antral follicle(s) increase estrogen receptor alpha (ESR1), progesterone receptor (PGR) and OXTR expression in the endometrium (Wathes \& Hamon 1993, Spencer \& Bazer 1995); however, the endometrium does not release PGF2 $\alpha$ as a CL is not present to produce oxytocin (OXT). During early diestrus, the newly formed $\mathrm{CL}$ produces progesterone that stimulates the accumulation of phospholipids in LE of the uterus, and those phospholipids serve as a source of arachidonic acid for PG synthesis. Progesterone levels then increase and act via PGR to inhibit or 'block' the expression of ESR1 and OXTR in the endometrial LE (McCracken et al. 1984). As a result, ESR1 and OXTR expression is not detectable during most of dioestrus (days 5-11). Continuous exposure of the uterus to progesterone for 8-10 days downregulates PGR expression in endometrial LE after day 10 (Spencer et al. 1995b), allowing for rapid increases in ESR1 expression on days 12 and 13 followed by OXTR on day 14 in cyclic and nonpregnant ewes (Hixon \& Flint 1987, Spencer et al. 1995a). The promoter of the ovine OXTR gene contains several SP1 elements that mediate responsiveness to ligand-activated ESR1 (Fleming et al. 2006). PTGS2 expression is also upregulated between days 10 and 12 post-oestrus/mating (Charpigny et al. 1997, Simmons et al. 2010). Oxytocin begins to be secreted from the posterior pituitary and/or CL beginning on day 9 of the oestrus cycle and pregnancy, and it acts on OXTR in the endometrial LE to induce production and release of luteolytic PGF2 $\alpha$ pulses between days 14 and 16 (Wathes \& Lamming 1995). As a result, the CL regresses, thereby allowing for the ewe to complete the 17-day oestrus cycle and return to oestrus. The timing of the

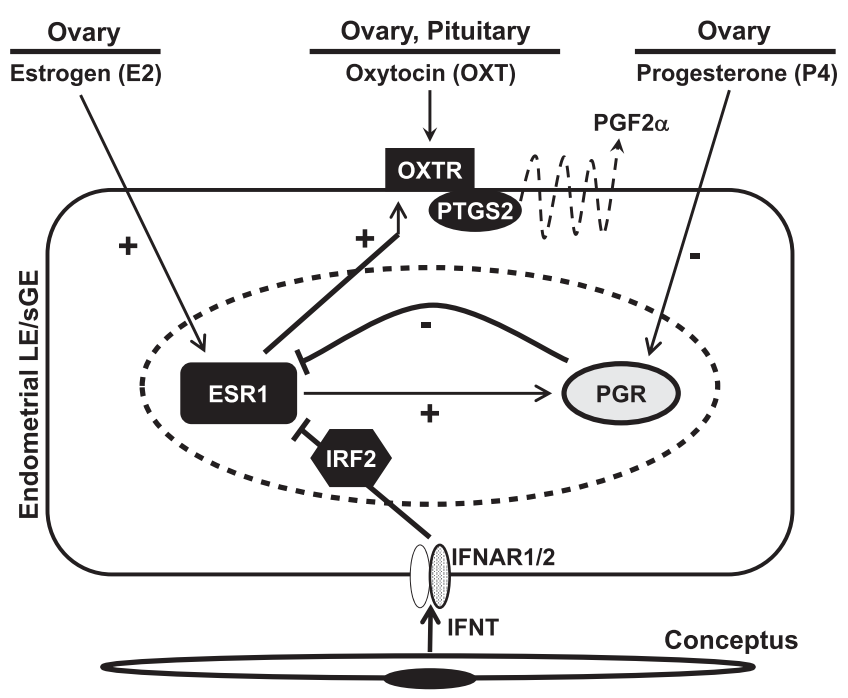

Figure 1 Schematic illustrating hormonal regulation of the endometrial luteolytic mechanism and antiluteolytic paracrine effects of conceptus interferon tau (IFNT) on the ovine uterine endometrium. During oestrus and metestrus, expression of oxytocin receptors (OXTR) by uterine lumenal and superficial ductal glandular epithelia (LE) increase in response to estrogens from the ovarian follicles that first stimulate the expression of estrogen receptor alpha (ESR1) and estrogens act via ESR1 to increase OXTR. Progesterone receptors (PGR) are expressed by LE during metestrus and diestrus, but low systemic levels of progesterone are insufficient to act via PGR to suppress ESR1 and OXTR gene expression. During early diestrus, endometrial ESR1 and oestrogen are low, but progesterone levels begin to increase with formation of the corpus luteum $(\mathrm{CL})$.

Progesterone acts through the PGR to suppress ESR1 and OXTR synthesis for 8-10 days. Continuous exposure of the endometrium to progesterone eventually downregulates PGR gene expression in the endometrial LE by days 11-12 of the oestrus cycle. The loss of PGR terminates the progesterone block to ESR1 and OXTR formation. Thus, ESR1 appears between days 11 and 12 post-oestrus, which is closely followed by increases in OXTR on days 13 and 14. The increase in OXTR expression is facilitated by increasing the secretion of estrogens by ovarian follicles. In both cyclic and pregnant ewes, oxytocin is released from the posterior pituitary and ovarian corpus luteum beginning on Day 9. In cyclic ewes, OXT binds to OXTR on $\mathrm{LE}$ and increases the release of luteolytic pulses of prostaglandin F2 $\alpha$ (PGF2 $\alpha$ ) to regress the CL through a PTGS2-dependent pathway. In pregnant ewes, IFNT is synthesized and secreted by the elongating conceptus beginning on Day 10 of pregnancy. IFNT binds to type I IFN receptors (IFNAR) on the endometrial LE and inhibits transcription of the ESR1 gene through a signaling pathway involving interferon regulatory factor two (IRF2). These antiluteolytic actions of IFNT on the ESR1 gene prevent OXTR formation, thereby maintaining the $\mathrm{CL}$ and progesterone production required for establishment and maintenance of pregnancy. E2, estradiol; ESR1, estrogen receptor alpha; IFNAR, type I IFN receptor; IFNT, interferon tau; IRF2, interferon regulatory factor two; OXT, oxytocin; OXTR, oxytocin receptor; P4, progesterone; PGF, prostaglandin F2 $\alpha$; PGR, progesterone receptor; PTGS2, prostaglandin-endoperoxide synthase 2 (prostaglandin G/H synthase and cyclooxygenase).

PGR downregulation by progesterone determines when the luteolytic mechanism develops in the endometrium in both sheep and cattle (Woody et al. 1967, Garrett et al. 1988, Morgan et al. 1993). Thus, progesterone 
first suppresses and then induces the development of the endometrial luteolytic mechanism in cyclic ewes. In cattle, oxytocin may have a more modulatory and auxiliary role in luteolysis, as opposed to the mandatory role for oxytocin in sheep (Hansel \& Blair 1996, Kotwica et al. 1997, Binelli et al. 2000).

\section{Pregnancy recognition and IFNT}

Embryo transfer experiments initially defined the maternal recognition of pregnancy period in sheep (Moor et al. 1969). Moor and Rowson found that a sheep conceptus must be present in the uterus by days 12 or 13 of the cycle in order for a successful pregnancy to be obtained following embryo transfer (Moor \& Rowson $1966 a, b)$. Removal of the conceptus from the uterus before day 13 had no effect on oestrus cycle length, whereas removal after day 13 extended $C L$ lifespan past day 17. Similar experiments were conducted in cattle (Betteridge et al. 1978). Those studies defined that maternal recognition of pregnancy occurs on days 12-13 in sheep and days 16-17 in cattle and involves a product(s) of the conceptus.

Accordingly, a combination of in vitro and in vivo experiments resulted in the purification of the pregnancy recognition signal IFNT and discovery that it is a type I IFN and the exclusive antiluteoytic factor secreted by the ruminant conceptus (Roberts et al. 2008a, Bazer et al. 2015). IFNT is expressed specifically by the mononuclear trophectoderm cells of the conceptus and peaks around day 15 (sheep) and day 20 (cattle) (Godkin et al. 1984b, Farin et al. 1989, Guillomot et al. 1990). Although low amounts of IFNT can be detected from day 8 or 10 blastocysts in sheep (Ashworth \& Bazer 1989), production of IFNT is maximal by the elongating conceptus on days 14-16 and then declines to undetectable levels by day 25 (Bazer et al. 1992, Roberts et al. 1999). Thus, IFNT production by the conceptus is initiated prior to the formation of OXTR in the endometrial epithelium in cyclic or nonpregnant ewes and cows.

\section{Antiluteolytic paracrine effects of IFNT}

Research in sheep established that IFNT is the antiluteolytic factor produced by the conceptus that inhibits the development of the endometrial luteolytic mechanism (Vallet et al. 1988b). Intrauterine injections of purified or recombinant ovine (ro) IFNT into sheep (Godkin et al. 1984b, Vallet et al. 1988b, Ott et al. 1993), cattle (Knickerbocker et al. 1986a,b, Thatcher et al. 1986, Meyer et al. 1995, Thatcher et al. 2001) and goats (Newton et al. 1996) abrogated development of the endometrial luteolytic mechanism and extended CL lifespan.
The majority of studies on the cellular and molecular effects of IFNT as a pregnancy recognition signal have involved sheep (Fig. 1). A series of in vivo studies found that IFNT does not act to affect PGR expression in the endometrial epithelium during pregnancy (Spencer \& Bazer 1995, 1996, Spencer et al. 1995b). Rather, IFNT acts in a paracrine fashion on endometrial LE to suppress transcription of the ESR1 and OXTR genes (Spencer \& Bazer 1996, Spencer et al. 1996a, Fleming et al. 2001). The increases in ESR1 and OXTR gene expression detected in the uterine LE on days 11-17 post-oestrus in cyclic or nonpregnant sheep do not occur in pregnant sheep (Spencer \& Bazer 1995) or in cyclic sheep infused with rolFNT (Spencer et al. 1995C). By inhibiting OXTR expression, IFNT prevents the production of luteolytic pulses of PGF2 $\alpha$ by the endometrium. Of note, IFNT does not inhibit basal production of $\mathrm{PGF} 2 \alpha$, which is higher in pregnant than cyclic ewes; further, the conceptus and IFNT do not inhibit PTGS2 gene expression or activity in the endometrial LE (Charpigny et al. 1997, Kim et al. 2003b, Simmons et al. 2010, Dorniak et al. 2011). Thus, the antiluteolytic actions of IFNT are to prevent the increases in epithelial ESR1 and OXTR gene expression, which are oestrogen responsive, by directly inhibiting transcription of the ESR1 gene. The cellular and molecular mechanisms involved in IFNT inhibitory actions on the ovine ESR1 gene are not fully known, but appears to involve IFN regulatory factor two (IRF2) (Fleming et al. 2001). Of note, IFNT can not inhibit OXTR expression once it is initiated in the endometrial epithelium (Vallet \& Bazer 1989).

Similar to sheep, PGR decline to undetectable levels in the endometrial LE of both cyclic and pregnant cattle by day 13 post-oestrus, and OXTR do not develop in endometrial LE of pregnant as in cyclic or nonpregnant cattle after day 16 post-oestrus (Robinson et al. 1999, Okumu et al. 2010). In contrast to sheep, little or no change in ESR1 expression was observed in the uterine epithelia of pregnant as compared to nonpregnant cattle (Robinson et al. 1999). Thus, pregnancy and IFNT can inhibit OXTR expression independent of ESR1 in the endometrium of cattle. IRF2 also regulates the expression of the bovine OXTR gene (Telgmann et al. 2003), suggesting a common role of IRF2 in the antiluteolytic actions of IFNT on the endometrium to establish pregnancy. The absence of OXTR in the endometrium prevents the release of luteolytic pulses of PGF $2 \alpha$ by the endometrium (Thatcher et al. 1989, Spencer et al. 2007). However, IFNT does not inhibit expression of PTGS2, which is important for the generation of prostaglandins that regulate endometrial function and conceptus elongation during early pregnancy in sheep (Dorniak et al. 2011) and likely cattle (Spencer et al. 2013, Ribeiro et al. 2016). 


\section{Paracrine actions of IFNT to regulate conceptus elongation- and implantation-related genes in the endometrium}

Interferon tau is the only known IFN to act as a pregnancy recognition signal in ruminants, but IFNs or ISGs may have a biological role in establishment of pregnancy in other species including mice and humans (Hansen et al. 1999, Bazer et al. 2009a). The paracrine actions of IFNT on the endometrium stimulates expression of ISGs in the endometrium of both sheep and cattle that are hypothesized to regulate uterine fuctions important for conceptus elongation, implantation and establishment of pregnancy (Hansen et al. 1999, Spencer et al. 2008, Bazer et al. 2009a, Hansen et al. 2010). The interferon (alpha and beta) receptor (IFNAR) mediates IFNT actions (Hansen et al. 1989). The elongating ovine conceptus expresses IFNAR1/2 (Rosenfeld et al. 2002), and in vitro studies with ovine trophectoderm cells found that IFNT stimulates their proliferation and certain ISGs (Wang et al. 2013), supporting the idea that IFNT has an autocrine role in conceptus elongation. A recent in vivo loss-of-function study challenged that idea. In that study, translation of IFNT or IFNAR1/2 mRNAs was inhibited in the trophectoderm of the ovine conceptus using morpholino antisense oligonucleotides delivered into the uterine lumen via osmotic pumps from days 8 to 14 post mating (Brooks \& Spencer 2014). Elongating and filamentous type conceptuses were recovered from day 14 ewes infused with a control morpholino or IFNAR1/2 morpholinos. In contrast, severely growth-retarded and malformed conceptuses were recovered from IFNT morpholino-infused ewes with increased numbers of apoptotic trophectoderm cells. Thus, available studies support the idea that IFNT is a critical regulator of conceptus elongation, but those effects are indirect via paracrine effects on the endometrium, which is similar to the dual roles of the human pregnancy recognition signal, chorionic gonadotropin (Banerjee \& Fazleabas 2011).

\section{Classical type I IFN-stimulated genes in the endometrium}

A combination of transcriptional profiling and proteomic experiments elucidated genes stimulated or uniquely induced by IFNT in human cells, ovine endometrium, bovine endometrium and bovine peripheral blood mononuclear cells (PBMC) during early pregnancy (Hansen et al. 1999, Bauersachs et al. 2006, 2012, Spencer et al. 2007, 2008, Forde et al. 2009, 2011, Mansouri-Attia et al. 2009, Cerri et al. 2012, Forde \& Lonergan 2012, Spencer \& Hansen 2015, Biase et al. 2016). The vast bulk of genes induced or upregulated by IFNT are classical ISGs also associated with the effects of other type I IFNs, such as IFNA and IFNB, that are activated during innate immune responses to invading pathogens (RNA viruses, DNA viruses, intracellular bacteria, parasites) (Schneider et al. 2014).

A archetypical ISG that responds to IFNT in early pregnant ruminants is ISG15 (ISG15 ubiquitin-like modifier, also known as ubiquitin cross-reactive protein or ISG17). On days 10 or 11 of the oestrus cycle and pregnancy in sheep, ISG15 is expressed in LE of the uterus, but disappears from the LE by days 12-13 of pregnancy (Johnson et al. 1999b). As the conceptus begins to elongate on day 12 and secrete more IFNT, ISG15 is upregulated in the upper stroma and GE by days 13-14, while expression extends to the lower stroma, deep glands and myometrium as well as resident immune cells of the ovine uterus by days 15-16 of pregnancy (Johnson et al. 1999b, 2000a). As IFNT production by the conceptus declines, expression of ISG15 in the stroma and GE also declines between days 20 and 25 of pregnancy. Similar spatiotemporal alterations in ISG15 expression occur in the bovine uterus during early pregnancy (Johnson et al. 1999a, Austin et al. 2004).

A combination of studies with bovine endometrium, ovine endometrium and human fibroblast cells found that IFNT activates the canonical janus kinase-signal transducer and activator of transcription-IFN regulatory factor (JAK-STAT-IRF) signaling pathway used by other type I IFNs (Stark et al. 1998). All endometrial cell types express IFNAR1 and IFNAR2 subunits in sheep (Rosenfeld et al. 2002); however, in vivo studies revealed that most classical ISGs are not induced or upregulated by IFNT in the LE of the ovine uterus during early pregnancy (Johnson et al. 1999b, 2001, Choi et al. 2001, 2003, Song et al. 2007). Further studies revealed that IRF2, a potent transcriptional repressor of ISGs (Taniguchi et al. 2001), is expressed specifically in the uterine LE and represses activity of IFN-stimulated response element (ISRE)-containing promoters (Spencer et al. 1998, Choi et al. 2001). Indeed, all components of the ISGF3 transcription factor complex (STAT1, STAT2, IRF9) and most classical ISGs (B2M, GBP2, IFI27, IFIT1, ISG15, MIC, OAS) contain one or more ISRE in their promoters. Thus, constitutive expression of IRF2 in the LE was hypothesized to restrict induction of most classical ISGs by IFNT in the stroma and GE of the uterus (Dorniak et al. 2013a). In endometrial LE during pregnancy, the lack of ISG induction and silencing of ISGs, such as $\mathrm{MHC}$ and $\mathrm{B} 2 \mathrm{M}$, may be a critical mechanism preventing immune rejection of the semi-allogeneic conceptus (Choi et al. 2003). Although type I IFNs are involved in both innative and adaptive immune responses in other species, little information is available on the role of IFNT in the immunology of the uterus and pregnancy.

A significant challenge is to determine which of the classical ISGs induced in the endometrium by IFNT have a biological role in conceptus elongation and/ or establishment of pregnancy. CXCL10 (chemokine (C-X-C motif) ligand 10 or IP-10) is one classical ISG 
that stimulates trophectoderm growth and adhesion in vitro (Nagaoka et al. 2003a,b). Other chemokines, such as CXCL12 in sheep (Ashley et al. 2011) and CCL8 and CCL11 in cattle (Sakumoto et al. 2017), may also have a role in conceptus-endometrial interactions. Thus, it is likely that other classical ISGs have biological roles in conceptus elongation and implantation in ruminants, particularly since IFNT has embryotrophic effects mediated by the endometrium (Dorniak et al. 2013b, Brooks \& Spencer 2015).

\section{Non-classical IFNT-stimulated genes in the endometrium}

A number of approaches, including microarray analysis of human U3A (STAT1 null) cells and ovine endometrium and in situ hybridization analysis, were used to discover IFNT-regulated genes in the uterine LE during pregnancy (Kim et al. 2003a, Song et al. 2005, $2006 b$ Gray et al. 2006, Satterfield et al. 2006). In sheep, IFNT was found to stimulate the expression of a number of genes (CST3, CST6, CTSL, GRP, HSD11B1, IGFBP1, LGALS15, SLC2A1, SLC2A5, SLC5A11, SLC7A2) in the endometrial LE and (or) GE that have biological activities potentially important for conceptus elongation and implantation (Spencer et al. 2007, 2008) (Table 1). Of note, none of those genes are classical ISGs induced

Table 1 Effects of ovarian progesterone (P4) and intrauterine infusion of interferon tau (IFNT) or prostaglandins (PGs) on elongation- and implantation-related genes expressed in the endometrial epithelia of the ovine uterus ${ }^{\mathrm{a}}$.

\begin{tabular}{|c|c|c|}
\hline Gene symbol and general function & $\mathbf{P 4}$ & IFNT \\
\hline \multicolumn{3}{|l|}{ Transport of glucose } \\
\hline$S L C 2 A 1$ & $\uparrow$ & + \\
\hline$S L C 2 A 5$ & n.d. & n.e. \\
\hline$S L C 2 A 12$ & n.d. & + \\
\hline SLC5A1 & $\uparrow$ & + \\
\hline SLC5A11 & $\uparrow$ & + \\
\hline \multicolumn{3}{|l|}{ Transport of amino acids } \\
\hline SLC1A5 & n.d. & n.d. \\
\hline SLC7A2 & $\uparrow$ & + \\
\hline \multicolumn{3}{|c|}{ Cell proliferation, migration, attachment } \\
\hline$G R P$ & $\uparrow$ & + \\
\hline IGFBP1 & $\uparrow$ & + \\
\hline LGALS15 & $\uparrow$ & ++ \\
\hline SPP1 & $\uparrow$ & + \\
\hline \multicolumn{3}{|l|}{ Proteases and their inhibitors } \\
\hline CTSL1 & $\uparrow$ & ++ \\
\hline CST3 & $\uparrow$ & + \\
\hline CST6 & & + \\
\hline \multicolumn{3}{|l|}{ Intracellular enzymes } \\
\hline HSD11B1 & $\uparrow$ & + \\
\hline PTGS2 & $\uparrow$ & n.e. ${ }^{b}$ \\
\hline \multicolumn{3}{|l|}{ Transcription factors } \\
\hline HIF1A & $\uparrow$ & + \\
\hline HIF $2 A$ & $\uparrow$ & + \\
\hline
\end{tabular}

aEffect of hormone or factor denoted as induction $(\uparrow)$, stimulation $(+)$, no effect (n.e.), decrease (-) or not determined (n.d.).

${ }^{b}$ No effect (n.e.) on gene expression, but increases PTGS2 activity. by other type I IFNs; thus, they were referred to as 'nonclassical' IFNT-stimulated genes. Further, those genes must be first induced by progesterone in the endometrial epithelia before IFNT can stimulate their expression. Many non-classical IFNT-stimulated genes identified to date have biological activities that implicate them in trophectoderm (proliferation, migration, attachment and (or) adhesion, nutrient transport) (Spencer et al. 2004a, 2008, Bazer et al. 2011, 2012, Dorniak et al. 2013a) (Table 1). For example, knockdown of an amino acid transporter (SLC7A1) in the conceptus trophectoderm (Wang et al. 2014) and inhibition of HSD11B1 activity in utero or in the conceptus trophectoderm compromised conceptus elongation in sheep (Dorniak et al. 2013b, Brooks et al. 2015). Of note, IFNT actions on the bovine endometrium are not as well understood in terms of non-classical IFNT-stimulated genes, but recent transcriptomic studies have started to uncover them (Forde et al. 2011, 2012, Bauersachs et al. 2012, Lonergan \& Forde 2014, Bauersachs \& Wolf 2015).

Critical signaling components of the JAK-STAT signaling system (STAT1, STAT2, IRF9) are not expressed in endometrial LE (Choi et al. 2001). Thus, it was reasoned that IFNT regulates the expression of genes in endometrial LE of the ovine uterus using a noncanonical, STAT1-independent signaling pathway. Indeed, other type I IFNs utilize noncanonical mitogen-activated protein kinase (MAPK) and phosphatidylinositol 3-kinase (PI3K) cascades (Platanias 2005). In ovine endometrium and LE cells in vitro, IFNT activates distinct JAK, epidermal growth factor receptor, MAPK (ERK1/2), PI3K-AKT and(or) Jun N-terminal kinase (JNK) signaling modules to regulate expression of PGE2 receptors (Banu et al. 2010, Lee et al. 2012a). Additionally, PTGS2derived prostaglandins and HSD11B1-derived cortisol are part of the noncanonical pathway of IFNT action on the endometrium in sheep (Dorniak et al. 2011, 2012, Brooks et al. 2015). Available evidence supports the idea that combinatorial paracrine effects of IFNT, via canonical and noncanonical signaling pathways, stimulates biological processes in the endometrium that regulate conceptus elongation for the establishment of pregnancy. Future investigations should focus on understanding the biological roles of classical and non-classical IFNT-stimulated genes as well as genes downregulated by IFNT in pregnancy establishment.

\section{IFNT and the servomechanism regulating uterine gland function in sheep}

In ruminants, a servomechanism involving ovarian hormones (oestrogen and progesterone) and placental factors (IFNT and $\mathrm{CSH} 1$ ) has been proposed to regulate endometrial function during pregnancy (Spencer \& Bazer 2002, Spencer et al. 2004c, Bazer et al. 2009b). In sheep, CSH1 (chorionic somatomammotrophin hormone one or placental lactogen) is produced by 
binucleate cells of the placenta beginning on days 15-16 of pregnancy, which is coordinate with the onset of expression of several progesterone-induced genes in the uterine glands that include SERPINA14 (serine peptidase inhibitor, clade A (alpha-1 antiproteinase, antitrypsin)-like or uterine milk proteins or UTMP), SPP1 (secreted phosphoprotein 1 or osteopontin), GRP (gastrin-releasing peptide) and STC1 (stanniocalcin one) (Ing et al. 1989, Whitley et al. 1998, Stewart et al. 2000, Song et al. 2006a). The prolactin receptor, which is involved in $\mathrm{CSH} 1$ action, is uniquely expressed in the GE (Cassy et al. 1999, Stewart et al. 2000, Noel et al. 2003). Available evidence supports the idea that sequential exposure of the ovine uterus to oestrogen, progesterone, IFNT and $\mathrm{CSH} 1$ activates and maintains endometrial gland differentiation and secretory function during gestation (Spencer \& Bazer 2002, Spencer et al. 2004c, Bazer et al. 2009b). Treatment of ovariectomized ewes with progesterone alone for at least 14 days induces SPP1, UTMP and STC1 expression by GE (Spencer et al. 1999b, Johnson et al. 2000b, Song et al. 2006a). Intrauterine infusions of $\mathrm{CSH} 1$ further increased SPP1, STC1 and SERPINA14 expression, but only when ewes received progesterone and intrauterine infusions of IFNT (Spencer et al. 1999b, Noel et al. 2003). The effects of IFNT may be attributed, in part, to increasing PRLR expression in the GE (Martin et al. 2004). The pathways mediating the interactive effects of IFNT and $\mathrm{CSH} 1$ on uterine gland function in ruminants remain unknown.

\section{Endocrine actions of IFNT}

Embryo transfer and uterine ligation experiments in the late 1960s and 1970s (Moor \& Rowson 1966a, Mapletoft et al. 1976b) described a local/ipsilateral effect of the conceptus in maintaining the $\mathrm{CL}$ during early pregnancy. In those experiments, ligation of the gravid horn protected the $C L$ ipsilateral to the conceptus, while the contralateral $\mathrm{CL}$ regressed, suggesting that preservation of the $\mathrm{CL}$ did not involve a systemic mediator. This finding was a primary reason why a paracrine action of conceptus secretory proteins on the endometrium was researched since the 1970s. Additional studies did not resolve the mechanism for the resistance of the $C L$ of pregnancy to the lytic effects of PGF2 $\alpha$ (Inskeep et al. 1975, Mapletoft et al. 1976a, Pratt et al. 1977, Silvia \& Niswender 1984), particularly considering that more PGF2 $\alpha$ is released from the uterus through the uterine vein in day 13 pregnant as compared to cyclic ewes (Wilson et al. 1972, Arosh et al. 2016).

\section{Navigation of IFNT beyond the luminal epithelium of the uterus}

Methods to detect IFNT expression and bioactivity were developed subsequent to its identification as the pregnancy recognition signal in sheep and cattle. Radioimmunoassay (RIA) with polyclonal antibody against native IFNT detected $2 \mathrm{ng}$ of IFNT per $\mathrm{ml}$ in media from cultured ovine conceptuses (Vallet et al. 1988a). In sheep, the release of IFNT from a cultured ovine conceptus was detected as early as day $8(\sim 1 \mathrm{ng} / \mathrm{h})$ and increased linearly through day $16(\sim 7 \mu \mathrm{g} / \mathrm{h})$ of pregnancy in sheep (Ashworth \& Bazer 1989). Another RIA with a sensitivity of $6.1 \mathrm{ng} / \mathrm{mL}$ was developed that detected IFNT in uterine luminal fluid of cattle (Takahashi et al. 2005). Similarly, IFNT antiviral bioactivity increased appreciably in conceptus culture media from days 12 to 14 (Pontzer et al. 1988). Early attempts to detect IFNT in systemic fluids, such as urine and cervical mucus, using western blot analysis with a $1 \mathrm{ng} / \mathrm{mL}$ limit of detection were not successful (Kazemi et al. 1988). More recently, IFNT was not detected in uterine vein or ovarian artery and vein blood on days 12-16 of pregnancy using western blot and enzyme-linked immunosorbent assays with unknown limits of detection (Lee et al. $2012 b$ ) or $1 \mathrm{ng} / \mathrm{mL}$ limit of detection (Arosh et al. 2016). These results, coupled with the lack of detection of radiolabeled ovine IFNT in maternal blood after infusion into the uterine lumen of ewes (Godkin et al. 1984a), lead to the conclusion that IFNT does not exit the uterus and only exerts paracrine actions on the endometrium.

Indirect evidence to support a role for IFNT outside of the uterus in ruminants includes induction of ISG15 in endometrial cells that are located more distally in the uterus. For example, ISG15 mRNA was localized to the deep epithelial as well as myometrial layers of the early pregnant uterus in cows (Johnson et al. 1999a) and ewes (Johnson et al. 1999b). Other ISGs, such as MX1 and MX2, had a similar distribution in the uterus during pregnancy in sheep (Ott et al. 1998). It was hypothesized that expression of ISGs in the uterine stroma and myometrium was induced directly by IFNT or indirectly via an IFNTomedin (Spencer et al. 1996b). The idea that IFNT could cross the endometrial LE was further supported by the observation that the uterine LE lose junctional complex proteins after day 12 of pregnancy, thus making those epithelia 'leaky' (Satterfield et al. 2007). Recent studies propose another mechanism of IFNT transport into the endometrium involving extracellular vesicles (exosomes and microvesicles) that are produced by the conceptus. Two studies have identified IFNT in extracellular vesicles recovered from uterine luminal fluid of pregnant ewes (Ruiz-Gonzalez et al. 2015, Nakamura et al. 2016). Fluorescent-labeled extracellular vesicles, isolated from conceptus-conditioned media and infused into the uterine lumen from days 8 to 14 of the oestrus cycle, were only observed in the uterine LE and not in the deeper glands, stroma or myometrium or other maternal tissues such as the ovary, CL, parametrial lymph nodes or lung (Burns et al. 2016). However, the small number and size of the labeled extracellular vesicles may have 
precluded their detection in that study. IFNT could also exit the uterus through the lymphatic system, but antiviral activity was not detected in lymph draining the uterus during pregnancy (Lamming et al. 1995). Further, iliac and submandibular lymph node ISG15 mRNA concentrations are low in day 15 pregnant ewes and not different from nonpregnant ewes (Antioniazzi \& Hansen, personal communication).

The first indication that IFNT might be released into the uterine vein during early pregnancy and have endocrine effects was reported by Schalue-Francis and coworkers (Schalue-Francis et al. 1991). In that study, 58 antiviral units per $\mathrm{ml}$ of IFN activity was detected in uterine vein serum from day 15 pregnant ewes, but antiviral activity was not found in sera from the ovarian artery or jugular vein during pregnancy, prompting the conclusion that IFNT might be rapidly cleared from the systemic circulation. A more recent study found significant antiviral activity in uterine vein blood of day 15 pregnant sheep (Oliveira et al. 2008). Despite the day 14-15 conceptus producing 20,000,000 antiviral units or about $200 \mu \mathrm{g}$ IFNT each day, it was determined that the amount of IFNT in the uterine vein blood was only $5-10 \mathrm{ng} / \mathrm{mL}$ (Romero et al. 2015), which is similar to the amounts of antiviral activity in uterine vein serum (Schalue-Francis et al. 1991). Antiviral activity was observed in the uterine vein, but not uterine artery serum, of day 15 pregnant when compared to cyclic sheep (Bott et al. 2010). Using a validated RIA, IFNT was detected in the uterine vein serum of ewes on days 15 and 16 of pregnancy (Romero et al. 2015).

The affinity of IFNT for the type I IFN receptor is exceptionally high (Kd of 10-11 M) (Hansen et al. 1989, Li \& Roberts 1994), which means that this receptor can become activated at very low IFN concentrations. Indeed, ISG15 expression can be induced in cultured small, large and mixed luteal cell cultures with as little as $100 \mathrm{pg} / \mathrm{mL}$ IFNT in sheep (Antoniazzi et al. 2013) and cattle (Hansen et al. 2017). Most of the historical assay sensitivities for IFNT are only $1 \mathrm{ng} / \mathrm{mL}$ and would fail to detect IFNT as it circulates below that concentration. Thus, the difficulty in detecting IFNT in peripheral serum may be caused by very low circulating levels of IFNT that are below the limits of detection using current technologies. Alternatively, IFNT may not be detectable because it is not the cytokine released from the uterine vein that induces ISGs in peripheral tissues.

\section{Systemic actions and effects of IFNT}

Available correlative studies in sheep support the idea that IFNT from the elongating conceptus exits the uterus via the uterine vein (Oliveira et al. 2008, Romero et al. 2015), thereby inducing the expression of ISGs in maternal tissues and cells including PBMC, liver and CL (Oliveira et al. 2008, Bott et al. 2010, Ribeiro et al. 2014, Meyerholz et al. 2016, Sinedino et al. 2017). Examination of PBMC revealed that ISGs were upregulated in response to early pregnancy in both sheep (Yankey et al. 2001) and cattle (Han et al. 2006, Gifford et al. 2007). This pregnancyassociated induction of ISGs in PBMC was further examined using microarray studies, which revealed many hundreds of genes were upregulated and downregulated in PBMC from cattle in response to pregnancy on day 18 (Hansen et al. 2010). Exogenous rolFNT, delivered into the uterine vein of cyclic sheep, upregulated ISG15 in the liver (Antoniazzi et al. 2013). Liver biopsies had increased MX1 and ISG15 mRNA in day 18 pregnant as compared to cyclic Holstein-Friesian heifers (Meyerholz et al. 2016), corroborating the idea of systemic release and endocrine actions of IFNT.

In sheep, induction of ISG15 expression was found in the CL following subcutaneous (Spencer et al. 1999a) and intramuscular injections (Chen et al. 2006) of rolFNT given from days $11-17$ of the oestrus cycle. The induction of ISG15 mRNA in the CL occurred in response to uterine luminal infusion or intramuscular injection of $2 \mathrm{mg}$ rolFNT, but not following intramuscular injection of $200 \mu \mathrm{g}$ rolFNT, suggesting a dose effect of rolFNT with this method of delivery. Successively, rolFNT was directly infused into the uterine vein of sheep using osmotic pumps that delivered $200 \mu \mathrm{g}$ rolFNT over a 24-h period (Hansen et al. 2010) and induced ISG15 mRNA in the ipsilateral and contralateral $C L$ as well as in the endometrium and liver (Oliveira et al. 2008, Bott et al. 2010). Continuous systemic delivery of rolFNT from days 10 to 17 of the oestrus cycle delayed return to oestrus in sheep. In that study, control (bovine serum albumin)-infused ewes returned to oestrus by day 19 , whereas rolFNT-infused ewes had oestrus cycles that were delayed to at least day 32, when presence of the original CL marked in ink at the time of pump installation was confirmed at necropsy. Thus, endocrine delivery of IFNT into the uterine vein blocked endogenously induced luteolysis.

To determine if IFNT could directly protect the CL (Bott et al. 2010), $200 \mu \mathrm{g}$ rolFNT per day was delivered into the uterine vein using miniosmotic pumps beginning on day 10 (prior to endogenous action of PGF $2 \alpha$ ). After $12 \mathrm{~h}$, the ewes received a single luteolytic pulse of PGF2 $\alpha$ (Silvia \& Niswender 1984, 1986, Silva et al. 2000, Bott et al. 2010). The luteolytic pulse of PGF2 $\alpha$ caused a decline in serum progesterone in control-infused but not ewes infused with rolFNT (Bott et al. 2010, Antoniazzi et al. 2013). When infusion of rolFNT was reduced to only $20 \mu \mathrm{g} /$ day $(833 \mathrm{ng} / \mathrm{h})$ into the uterine vein or jugular vein on days 10-13, the CL was protected from the luteoytic action of PGF $2 \alpha$ exogenously administered on day 11 (Antoniazzi et al. 2013). Thus, the induction of ISGs in the $\mathrm{CL}$ and resistance to luteolytic PGF2 $\alpha$ appears to to be maximized with lower doses of rolFNT rather than single or multiple injections of high doses of rolFNT, which likely better reflect conditions in vivo during a normal pregnancy. 


\section{Induction of ISGs during pregnancy in extrauterine tissues}

In sheep, ISGs are induced by pregnancy in extrauterine tissues including the PBMC, CL and liver. For example, ISG15 mRNA and protein are upregulated in $\mathrm{CL}$ on day 15 (Oliveira et al. 2008, Bott et al. 2010, Romero et al. 2013). ISG15 and its ISGylated protein targets were predominantly localized to large luteal cells on day 15 of pregnancy with diminished but significant localization to small luteal cells. Pregnancy-associated ISGs are induced in small, large and mixed luteal cells isolated on day 10 of the oestrus cycle and cultured with rolFNT for $24 \mathrm{~h}$ (Antoniazzi et al. 2013). Morevover, ISGs are upregulated in the $\mathrm{CL}$ during the maternal recognition of pregnancy period (Romero et al. 2013). Evaluation of physiological responses in the CL lead to the conclusion that pregnancy may provide luteal resistance to PGF2 $\alpha$ through activation or stabilization of gene expression associated with IFN, chemokine, cell adhesion, cytoskeletal and angiogenic pathways. Cell survival genes induced by IFNT in the CL may also play important roles in sustaining luteal steroidogenesis by inhibiting apoptosis of luteal cells (Antoniazzi et al. 2013). Collectively, these responses to IFNT direct the luteal environment to continue to produce progesterone and to be resistant to the luteolytic effects of PGF $2 \alpha$.

In cattle, ISG15 expression also is upregulated in the $\mathrm{CL}$ as early as day 16 of pregnancy and continues to be detected in the $\mathrm{CL}$ through day 60 of pregnancy (Yang et al. 2010, Magata et al. 2012). Both free and ISG15-conjugated proteins were upregulated in bovine small luteal and large luteal cells following culture with rbIFNT (Nitta et al. 2011, Hansen et al. 2017). Pregnancy also induces lymphoangiogenesis in the bovine $\mathrm{CL}$ via the vascular endothelial growth factor (VEGF) system (Miyamoto et al. 2014). Key intraluteal regulators induced by pregnancy may involve influx of neutrophils as well as an increase in interleukin 8 chemokine expression to complement continued steroidogenesis (Shirasuna et al. 2015). Pregnancy, via IFNT may also downregulate genes detrimental to $\mathrm{CL}$ survival and function. For example, expression of tumor necrosis alpha (TNFA), an inflammatory cytokine secreted mainly by macrophages, was reduced in pregnancy, suggesting qualitative changes in macrophages within the $\mathrm{CL}$ (Shirasuna et al. 2015). This is consistent with and would complement a general upregulation of cell life genes in ovine CL in response to pregnancy (Romero et al. 2013). The specific endocrine effects of IFNT and ISGs on the bovine $\mathrm{CL}$ remain to be elucidated.

\section{IFNT, ISGs and pregnancy diagnosis}

Diagnosis of pregnancy is integral to management of beef and dairy cattle. The identification of nonpregnant cows as soon as possible following artificial insemination would allow producers to better manage return to pregnancy and entry into optimal milk (dairy) and meat (dairy and beef) production. Current traditional methods of pregnancy diagnosis focus on per rectum ultrasound on day 32 or transrectal palpation of the reproductive tract around day 40. New indirect chemical methods for pregnancy diagnosis include the detection of pregnancy-associated glycoprotein (PAG or pregnancy specific protein B) in blood on days 24-32 following artificial insemination (AI). Determination of pregnancy status prior to day 32 would have tremendous economic benefit to cattle producers (Hansen \& Galligan 2007). If inseminated cows that failed to conceive and maintain pregnancy were identified through lack or suboptimal detection of a conceptus-induced ISG(s) in the maternal circulation at days $18-20$, a rapid resynchronization of the oestrus cycle could be performed, thereby reducing the calving interval and improving the profitability of dairy operations (De Vries 2006).

Because IFNT is expressed and induces ISGs in the endometrium during pregnancy recognition, it was reasoned that surrogate markers for pregnancy or IFNT might be present in the blood and provide an indicator of pregnancy status in cattle. Historical assays for IFNT did not have sensitivity beyond the low ng levels, thus studies focused on ISGs. The concept of detecting ISGs in blood as indicators of pregnancy is not new (Hansen \& Rueda 1991), but there are currently no ISG-based protein biomarkers in blood that are useful to determine pregnancy status. In sheep, the levels of MX1 mRNA were greater in PBMC from day 15 through day 30 after insemination in pregnant as compared with nonpregnant ewes (Yankey et al. 2001). Similar effects of pregnancy on ISGs in PBMC of cattle were observed (Han et al. 2006, Gifford et al. 2007). Overall, mean blood ISG15 mRNA levels are greater from day 15 to day 32 of gestation, with maximal levels on day 20 in pregnant compared with inseminated, nonpregnant cows. In addition, the detection of ISG15 mRNA in PBMC over several days was more accurate in predicting pregnancy when compared to a single determination. Further studies focusing on cattle under different production systems revealed that ISGs increased in leukocytes in response to pregnancy on day 18 in dairy heifers, but not in lactating dairy cows (Green et al. 2010, Monteiro et al. 2014). A similar study in beef cows demonstrated an increase in ISG mRNA between days 15 and 22 of pregnancy with a peak concentration on day 20 (Pugliesi et al. 2014). That study found that leukocyte ISG mRNA levels are a more accurate predictor of pregnancy when coupled with ultrasound determination of a $\mathrm{CL}$ on day 20 of pregnancy.

In cattle, the levels of ISG15 and MX2 mRNA in PBMC are positively correlated with the amount of IFNT infused in the uterus (Matsuyama et al. 2012). Interestingly, maternal treatment with recombinant bovine somatotropin during the pre- and 
peri-implantation period stimulated conceptus development and increased expression of ISG15 and RTP4 in blood leukocytes of lactating dairy cows (Ribeiro et al. 2014). Similar to sheep, conceptus length and IFNT mRNA are correlated (Bertolini et al. 2002). Loss of embryos in a model of induced embryo mortality is associated with diminished RTP4 and ISG15 mRNA levels in peripheral blood leukocytes in sheep (Kose et al. 2016). Stevenson and coworkers tested the reliability of using the change in one ISG (MX2) from steady-state levels on day 0 to days 18 and 19 after AI for identification of nonpregnant heifers (Stevenson et al. 2007). Although, the fold changes in ISG mRNA from day 0 to day 18 were greater for heifers diagnosed pregnant, the low sensitivity (the ability of the test to identify a pregnant cow) and negative predictive value (calculated as the proportion of nonpregnant outcomes generated by the pregnancy test that were from truly nonpregnant cows) precluded this approach for accurately detecting nonpregnant heifers at day 18 after Al. The abundance of ISG mRNA in maternal PBMC progressively increased from day 15 after $\mathrm{Al}$, peaked on day 20 and then decreased to day 22 (Pugliesi et al. 2014). In that study, ISG transcript abundance was greater on day 18 than day 15 for all ISGs (OAS1, ISG15, MX1, MX2) in pregnant when compared to nonpregnant beef cows, but the sensitivity and negative predictive value for the pregnancy detection were also low.

In pregnant Holstein-Friesian cows, investigators defined the shortest interval to pregnancy detection by measuring ISGs in blood on days 17 and 18 after $\mathrm{Al}$ in nulliparous, primiparous and multiparous cows (Green et al. 2010). The greatest amount of ISG was found in primiparous cows on day 20, which correlates with maximal production of IFNT by the elongated conceptus. There was a greater false-positive rate for lactating cows, suggesting that ISG-based diagnostics might be more feasible for nulliparous cows. Similarly, greater PBMC ISG15 and RTP4 levels were observed in primiparous than multiparous Holstein cows on day 19 (Sinedino et al. 2017). A possible explanation for the differences in ISG expression between heifers or primiparous and multiparous cows might be related to conceptus length, as it is longer in heifers when compared to cows during pregnancy recognition thus affecting the amount of IFNT produced (Berg et al. 2010). Another possible reason for improved peripheral ISG expression in heifers is that they are smaller than multiparous cows, which could affect systemic concentrations of IFNT and, consequently, the response of ISG in leukocytes. Green and coworkers tried to improve the accuracy of early pregnancy diagnosis by using the ratio of ISC expression on day 18 after AI to expression of ISG based on a baseline control blood sample collected before AI (Green et al. 2010). This approach improved the overall utility of the test, but would entail more blood sampling and might not be practical for an on-farm test.
Available studies in cattle support the idea that detection of ISGs in blood are a reasonable indicator of pregnancy status in ruminants, but improvements in methodology are needed, with more adequately defined cut-offs and easier on-farm and cost-effective methods. For example, Wiltbank and coworkers summarized 4 studies in which PBMC ISGs were assessed for early pregnancy diagnosis and reported that the false-negative results ranged from 10.1 to $17.5 \%$ (Wiltbank et al.

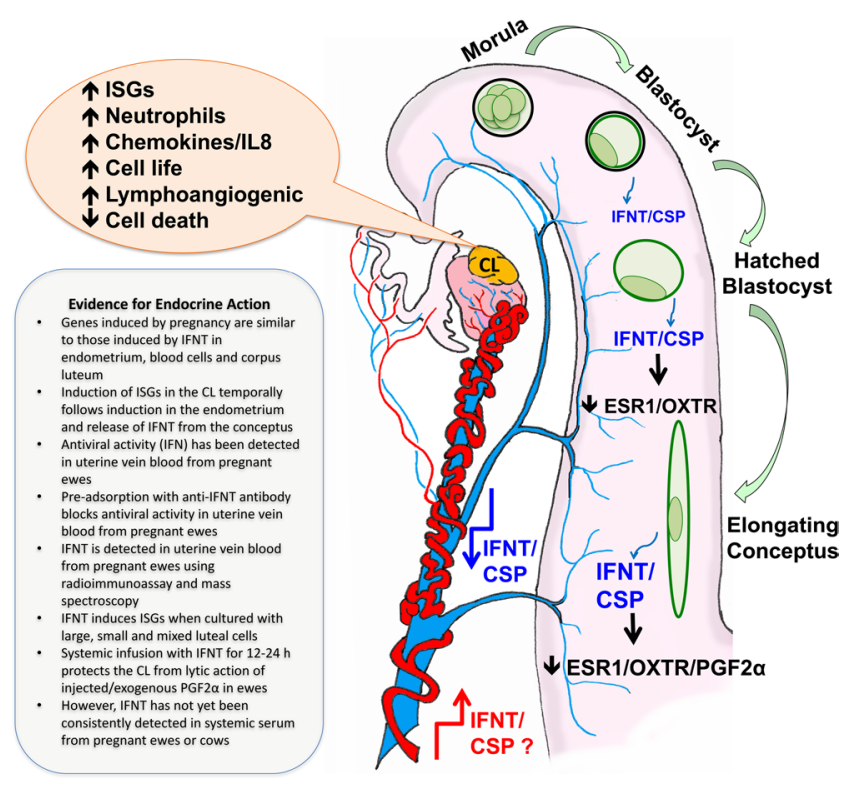

Figure 2 Endocrine action of pregnancy in ruminants. IFNT is a major conceptus secretory protein (CSP) that is released by the expanding and elongating blastocyst. IFNT has been shown to suppress the upregulation of ESR1, which leads to suppression of OXTR, disruption of pulsatile PGF2 $\alpha$ release and antiluteolytic action on the corpus luteum. The mechanism disrupting PGF may be slightly different in cattle and only involve effects on the OXTR. Regardless, paracrine action of IFNT alters PGF2 $\alpha$ pulses in both sheep and cattle and, thereby, protects the CL so that it can continue to produce progesterone, which supports production of histotroph and further development and attachment of the conceptus. In addition to activating ISGs in the endometrium, IFNT, in addition to other CSP, may be released into the uterine vein to act in peripheral/endocrine action on immune cells and the corpus luteum. The consequences of activated innate immune responses during establishment of pregnancy in ruminants is unknown and needs to be clarified as functionally important or simply consequential to massive release of IFNT by the developing conceptus. Concerns with utility of detection of ISGs in blood cells as indicators of pregnancy centers on massive induction of these same ISGs in response to viral infections and other inflammatory responses (i.e. bacterial infections such as mastitis in dairy cows). However, the endocrine action of pregnancy and IFNT when inducing ISGs in the CL may be relevant to establishment of luteal resistance to PGF2 $\alpha$. This is certainly implicated through studies demonstrating resistance of the $\mathrm{CL}$ induced by endocrine delivery of IFNT in response to both endogenous and exogenous PGF2 $\alpha$. CL, corpus luteum; CSP, conceptus secretory protein; ESR1, estrogen receptor alpha; IFNT, interferon tau; ISGs, interferon-stimulated genes; OXTR, oxytocin receptor; PGF2 $\alpha$, prostaglandin F2 alpha. 
2016). Another concern for this approach to pregnancy diagnosis in cattle is the considerable induction of ISGs by other type I IFNs (IFNA, IFNB, IFNW) that occurs in response to viral infections (Hansen et al. 2015) and pro-inflammatory stressors (Hansen et al. 2010). These false-positive responses might be managed by multiple blood samples including those outside of the maternal recognition window in order to find a baseline of ISG. Regardless, when used with other parameters such as serum progesterone, serum pregnancy-associated glycoproteins (PAGs) and ultrasound, detection of ISGs may be useful to determine pregnancy status and the timing of embryo loss in cattle (Wijma et al. 2016).

\section{Conclusions}

The antiluteolytic effects of IFNT in ruminants involve paracrine effects on the endometrium and endocrine effects on the $C L$ that culminate in maternal recognition of pregnancy and maintenance of progesterone production, the unequivocal hormone of pregnancy (Fig. 2). The production of sufficient IFNT to establish pregnancy is dependent on conceptus elongation. The individual, additive and synergistic actions of progesterone and IFNT regulate expression of elongation- and implantationrelated genes in the endometrium that, in turn, increase substances (e.g., glucose, amino acids, proteins, lipids) in the uterine lumen that govern conceptus survival and elongation. One important area of future research is determining which ISGs and impacted biological pathways are critical determinants of pregnancy establishment and success. Indirect and correlative evidence in sheep and cattle supports the concept that IFNT is released by the conceptus, navigates the endometrium, enters uterine vein blood and is delivered in amounts sufficient to induce ISGs in peripheral tissues (PBMC, CL, liver). Detection of antiviral activity specific to IFNT, immunoreactive IFNT in radioimmunoassay, and mass spectrometry detection of IFNT in uterine vein blood provides evidence that this occurs. The induction of peripheral ISGs is temporally related to the size of the conceptus and production of IFNT. Induction of ISGs in $\mathrm{PBMC}$ in response to pregnancy may have critical roles in prompting peripheral innate immune responses. The induction of ISGs in the CL may be important to sustain its function to produce progesterone and prevent the lytic effects of PGF2 $\alpha$. The development of a blood or milk test to better manage the open or nonpregnant cow is an area of current and future interest. Some focus has recently moved away from the ISGs as surrogate markers for IFNT action because of the false-positive issue in context of maternal infections and stressors during pregnancy. If IFNT is specifically and accurately detectable in peripheral fluids distal to the uterine vein, then it will be an outstanding candidate biomarker for an early pregnancy test.

\section{Declaration of interests}

There is no conflict of interest that could be perceived as prejudicing the impartiality of the research reported.

\section{Funding}

This research was supported, in part, by Agriculture and Food Research Initiative competitive grants 2010-38420-20397, 2011-67015-20067, 2012-67015-30173 and 2015-6701523678 from the U.S. Department of Agriculture, National Institute of Food and Agriculture and USDA (WAAESD) Regional Project: W2112; Reproductive Performance in Ruminants, through the CRC Program in the College of Veterinary Medicine and Biomedical Sciences, Colorado State University.

\section{References}

Antoniazzi AQ, Webb BT, Romero JJ, Ashley RL, Smirnova NP, Henkes LE, Bott RC, Oliveira JF, Niswender GD, Bazer FW et al. 2013 Endocrine delivery of interferon tau protects the corpus luteum from prostaglandin F2 alpha-induced luteolysis in ewes. Biology of Reproduction 88144. (doi:10.1095/biolreprod.112.105684)

Arosh JA, Banu SK \& McCracken JA 2016 Novel concepts on the role of prostaglandins on luteal maintenance and maternal recognition and establishment of pregnancy in ruminants. Journal of Dairy Science 99 5926-5940. (doi:10.3168/jds.2015-10335)

Ashley RL, Antoniazzi AQ, Anthony RV \& Hansen TR 2011 The chemokine receptor CXCR4 and its ligand CXCL12 are activated during implantation and placentation in sheep. Reproductive Biology and Endocrinology: $R B \& E 9148$.

Ashworth CJ \& Bazer FW 1989 Changes in ovine conceptus and endometrial function following asynchronous embryo transfer or administration of progesterone. Biology of Reproduction 40 425-433. (doi:10.1095/biolreprod40.2.425)

Austin KJ, Carr AL, Pru JK, Hearne CE, George EL, Belden EL \& Hansen TR 2004 Localization of ISG15 and conjugated proteins in bovine endometrium using immunohistochemistry and electron microscopy. Endocrinology 145 967-975. (doi:10.1210/en.2003-1087)

Banerjee P \& Fazleabas AT 2011 Extragonadal actions of chorionic gonadotropin. Reviews in Endocrine and Metabolic Disorders 12 323-332. (doi:10.1007/s11154-011-9193-1)

Banu SK, Lee J, Stephen SD, Nithy TK \& Arosh JA 2010 Interferon tau regulates PGF2alpha release from the ovine endometrial epithelial cells via activation of novel JAK/EGFR/ERK/EGR-1 pathways. Molecular Endocrinology 24 2315-2330. (doi:10.1210/me.2010-0205)

Bauersachs S \& Wolf E 2015 Uterine responses to the preattachment embryo in domestic ungulates: recognition of pregnancy and preparation for implantation. Annual Review of Animal Biosciences 3 489-511. (doi:10.1146/annurev-animal-022114-110639)

Bauersachs S, Ulbrich SE, Gross K, Schmidt SE, Meyer HH, Wenigerkind H, Vermehren M, Sinowatz F, Blum H \& Wolf E 2006 Embryo-induced transcriptome changes in bovine endometrium reveal species-specific and common molecular markers of uterine receptivity. Reproduction 132 319-331. (doi:10.1530/rep.1.00996)

Bauersachs S, Ulbrich SE, Reichenbach HD, Reichenbach M, Buttner M, Meyer HH, Spencer TE, Minten M, Sax G, Winter G \& Wolf E 2012 Comparison of the effects of early pregnancy with human interferon, alpha 2 (IFNA2), on gene expression in bovine endometrium. Biology of Reproduction 86 46. (doi:10.1095/biolreprod.111.094771)

Bazer FW, Thatcher WW, Hansen PJ, Mirando MA, Ott TL \& Plante C 1991 Physiological mechanisms of pregnancy recognition in ruminants. Journal of Reproduction and Fertility: Supplement 43 39-47.

Bazer FW, Mirando MA, Ott TL, Harney JP, Dubois DH, Schalue TK, Pontzer CH, Hostetler C, Johnson HM \& Ogle T 1992 Roles of ovine trophoblast protein-1 and oestradiol/prolactin in the establishment of 
pregnancy in sheep and pigs. Reproduction, Fertility and Development 4 335-340. (doi:10.1071/RD9920335)

Bazer FW, Spencer TE \& Johnson GA 2009a Interferons and uterine receptivity. Seminars in Reproductive Medicine 27 90-102. (doi:10.1055/ s-0028-1108013)

Bazer FW, Spencer TE, Johnson GA, Burghardt RC \& Wu G 2009b Comparative aspects of implantation. Reproduction 138 195-209. (doi:10.1530/REP-09-0158)

Bazer FW, Spencer TE, Johnson GA \& Burghardt RC 2011 Uterine receptivity to implantation of blastocysts in mammals. Frontiers in Bioscience 3 745-767. (doi:10.2741/s184)

Bazer FW, Kim J, Ka H, Johnson GA, Wu G \& Song G 2012 Select nutrients in the uterine lumen of sheep and pigs affect conceptus development. Journal of Reproduction and Development 58 180-188. (doi:10.1262/ jrd.2011-019)

Bazer FW, Ying W, Wang X, Dunlap KA, Zhou B, Johnson GA \& Wu G 2015 The many faces of interferon tau. Amino Acids 47 449-460. (doi:10.1007/s00726-014-1905-x)

Berg DK, van Leeuwen J, Beaumont S, Berg M \& Pfeffer PL 2010 Embryo loss in cattle between Days 7 and 16 of pregnancy. Theriogenology 73 250-260. (doi:10.1016/j.theriogenology.2009.09.005)

Bertolini M, Beam SW, Shim H, Bertolini LR, Moyer AL, Famula TR \& Anderson GB 2002 Growth, development, and gene expression by in vivo- and in vitro-produced day 7 and 16 bovine embryos. Molecular Reproduction and Development 63 318-328. (doi:10.1002/mrd.90015)

Betteridge KJ, Eaglesome ND, Randall GCB, Mitchell D \& Lugden EA 1978 Maternal progesterone levels as evidence of luteotrophic or antiluteolytic effects on embryos transferred to heifers 12-17 days after estrus. Theriogenology 9 86-93. (doi:10.1016/0093-691X(78)90054-7)

Biase FH, Rabel C, Guillomot M, Hue I, Andropolis K, Olmstead CA, Oliveira R, Wallace R, Le Bourhis D, Richard C et al. 2016 Massive dysregulation of genes involved in cell signaling and placental development in cloned cattle conceptus and maternal endometrium. PNAS 113 14492-14501. (doi:10.1073/pnas.1520945114)

Binelli M, Guzeloglu A, Badinga L, Arnold DR, Sirois J, Hansen TR \& Thatcher WW 2000 Interferon-tau modulates phorbol ester-induced production of prostaglandin and expression of cyclooxygenase- 2 and phospholipase-A(2) from bovine endometrial cells. Biology of Reproduction 63 417-424. (doi:10.1095/biolreprod63.2.417)

Bott RC, Ashley RL, Henkes LE, Antoniazzi AQ, Bruemmer JE, Niswender GD, Bazer FW, Spencer TE, Smirnova NP, Anthony RV et al. 2010 Uterine vein infusion of interferon tau (IFNT) extends luteal life span in ewes. Biology of Reproduction 82 725-735. (doi:10.1095/biolreprod.109.079467)

Brooks K \& Spencer TE 2015 Biological roles of interferon tau (IFNT) and type I IFN receptors in elongation of the ovine conceptus. Biology of Reproduction 92 47. (doi:10.1095/biolreprod.114.124156)

Brooks K, Burns G \& Spencer TE 2015 Biological roles of hydroxysteroid (11-Beta) dehydrogenase 1 (HSD11B1), HSD11B2, and glucocorticoid receptor (NR3C1) in sheep conceptus elongation. Biology of Reproduction 93 38. (doi:10.1095/biolreprod.115.130757)

Burns GW, Brooks KE \& Spencer TE 2016 Extracellular vesicles originate from the conceptus and uterus during early pregnancy in sheep. Biology of Reproduction 94 56. (doi:10.1095/biolreprod.115.134973)

Cassy S, Charlier M, Guillomot M, Pessemesse L \& Djiane J 1999 Cellular localization and evolution of prolactin receptor mRNA in ovine endometrium during pregnancy. FEBS Letters 445 207-211. (doi:10.1016/S0014-5793(99)00052-6)

Cerri RL, Thompson IM, Kim IH, Ealy AD, Hansen PJ, Staples CR, Li JL, Santos JE \& Thatcher WW 2012 Effects of lactation and pregnancy on gene expression of endometrium of Holstein cows at day 17 of the estrous cycle or pregnancy. Journal of Dairy Science 95 5657-5675. (doi:10.3168/jds.2011-5114)

Charpigny G, Reinaud P, Tamby JP, Creminon C, Martal J, Maclouf J \& Guillomot M 1997 Expression of cyclooxygenase-1 and -2 in ovine endometrium during the estrous cycle and early pregnancy. Endocrinology 138 2163-2171. (doi:10.1210/endo.138.5.5148)

Chen Y, Green JA, Antoniou E, Ealy AD, Mathialagan N, Walker AM, Avalle MP, Rosenfeld CS, Hearne LB \& Roberts RM 2006 Effect of interferontau administration on endometrium of nonpregnant ewes: a comparison with pregnant ewes. Endocrinology 147 2127-2137. (doi:10.1210/ en.2005-1310)
Choi Y, Johnson GA, Burghardt RC, Berghman LR, Joyce MM, Taylor KM, Stewart MD, Bazer FW \& Spencer TE 2001 Interferon regulatory factortwo restricts expression of interferon-stimulated genes to the endometrial stroma and glandular epithelium of the ovine uterus. Biology of Reproduction 65 1038-1049. (doi:10.1095/biolreprod65.4.1038)

Choi Y, Johnson GA, Spencer TE \& Bazer FW 2003 Pregnancy and interferon tau regulate $\mathrm{MHC}$ class I and beta-2-microglobulin expression in the ovine uterus. Biology of Reproduction 68 1703-1710. (doi:10.1095/ biolreprod.102.012708)

De Vries A 2006 Economic value of pregnancy in dairy cattle. Journal of Dairy Science 89 3876-3885. (doi:10.3168/jds.S00220302(06)72430-4)

Dorniak P, Bazer FW \& Spencer TE 2011 Prostaglandins regulate conceptus elongation and mediate effects of interferon tau on the ovine uterine endometrium. Biology of Reproduction 84 1119-1127. (doi:10.1095/ biolreprod.110.089979)

Dorniak P, Welsh TH Jr, Bazer FW \& Spencer TE 2012 Endometrial HSD11B1 and cortisol regeneration in the ovine uterus: effects of pregnancy, interferon tau, and prostaglandins. Biology of Reproduction 86 124. (doi:10.1095/biolreprod.111.097063)

Dorniak P, Bazer FW \& Spencer TE 2013a Physiology and endocrinology symposium: biological role of interferon tau in endometrial function and conceptus elongation. Journal of Animal Science 91 1627-1638. (doi:10.2527/jas.2012-5845)

Dorniak P, Welsh TH Jr, Bazer FW \& Spencer TE $2013 b$ Cortisol and interferon tau regulation of endometrial function and conceptus development in female sheep. Endocrinology 154 931-941. (doi:10.1210/en.2012-1909)

Farin CE, Imakawa K \& Roberts RM 1989 In situ localization of mRNA for the interferon, ovine trophoblast protein-1, during early embryonic development of the sheep. Molecular Endocrinology 3 1099-1107. (doi:10.1210/mend-3-7-1099)

Flechon JE, Guillomot M, Charlier M, Flechon B \& Martal J 1986 Experimental studies on the elongation of the ewe blastocyst. Reproduction Nutrition Development 26 1017-1024. (doi:10.1051/ rnd:19860609)

Fleming JA, Choi Y, Johnson GA, Spencer TE \& Bazer FW 2001 Cloning of the ovine estrogen receptor-alpha promoter and functional regulation by ovine interferon-tau. Endocrinology 142 2879-2887. (doi:10.1210/ endo.142.7.8245)

Fleming JG, Spencer TE, Safe SH \& Bazer FW 2006 Estrogen regulates transcription of the ovine oxytocin receptor gene through GC-rich SP1 promoter elements. Endocrinology 147 899-911. (doi:10.1210/ en.2005-1120)

Forde N \& Lonergan P 2012 Transcriptomic analysis of the bovine endometrium: What is required to establish uterine receptivity to implantation in cattle? Journal of Reproduction and Development $\mathbf{5 8}$ 189-195.

Forde N, Carter F, Fair T, Crowe MA, Evans AC, Spencer TE, Bazer FW, McBride R, Boland MP, O'Gaora P et al. 2009 Progesterone-regulated changes in endometrial gene expression contribute to advanced conceptus development in cattle. Biology of Reproduction 81 784-794. (doi:10.1095/biolreprod.108.074336)

Forde N, Carter F, Spencer TE, Bazer FW, Sandra O, Mansouri-Attia N, Okumu LA, McGettigan PA, Mehta JP, McBride R et al. 2011 Conceptusinduced changes in the endometrial transcriptome: How soon does the cow know she is pregnant? Biology of Reproduction 85 144-156.

Forde N, Duffy GB, McGettigan PA, Browne JA, Mehta JP, Kelly AK, Mansouri-Attia N, Sandra O, Loftus BJ, Crowe MA et al. 2012 Evidence for an early endometrial response to pregnancy in cattle: both dependent upon and independent of interferon tau. Physiological Genomics 44 799-810. (doi:10.1152/physiolgenomics.00067.2012)

Garrett JE, Geisert RD, Zavy MT, Gries LK, Wettemann RP \& Buchanan DS 1988 Effect of exogenous progesterone on prostaglandin F2 alpha release and the interestrous interval in the bovine. Prostaglandins $\mathbf{3 6}$ 85-96. (doi:10.1016/0090-6980(88)90104-9)

Gifford CA, Racicot K, Clark DS, Austin KJ, Hansen TR, Lucy MC, Davies CJ \& Ott TL 2007 Regulation of interferon-stimulated genes in peripheral blood leukocytes in pregnant and bred, nonpregnant dairy cows. Journal of Dairy Science 90 274-280. (doi:10.3168/jds.S00220302(07)72628-0) 
Godkin JD, Bazer FW \& Roberts RM 1984a Ovine trophoblast protein 1, an early secreted blastocyst protein, binds specifically to uterine endometrium and affects protein synthesis. Endocrinology 114 120-130. (doi:10.1210/endo-114-1-120)

Godkin JD, Bazer FW, Thatcher WW \& Roberts RM 1984b Proteins released by cultured Day 15-16 conceptuses prolong luteal maintenance when introduced into the uterine lumen of cyclic ewes. Journal of Reproduction and Fertility 71 57-64. (doi:10.1530/jrf.0.0710057)

Gray C, Bartol FF, Taylor KM, Wiley AA, Ramsey WS, Ott TL, Bazer FW \& Spencer TE 2000 Ovine uterine gland knock-out model: effects of gland ablation on the estrous cycle. Biology of Reproduction 62 448-456. (doi:10.1095/biolreprod62.2.448)

Gray CA, Burghardt RC, Johnson GA, Bazer FW \& Spencer TE 2002 Evidence that absence of endometrial gland secretions in uterine gland knockout ewes compromises conceptus survival and elongation. Reproduction 124 289-300. (doi:10.1530/rep.0.1240289)

Gray CA, Abbey CA, Beremand PD, Choi Y, Farmer JL, Adelson DL, Thomas TL, Bazer FW \& Spencer TE 2006 Identification of endometrial genes regulated by early pregnancy, progesterone, and interferon tau in the ovine uterus. Biology of Reproduction 74 383-394. (doi:10.1095/ biolreprod.105.046656)

Green JC, Okamura CS, Poock SE \& Lucy MC 2010 Measurement of interferon-tau (IFN-tau) stimulated gene expression in blood leukocytes for pregnancy diagnosis within 18-20d after insemination in dairy cattle. Animal Reproduction Science 121 24-33. (doi:10.1016/j. anireprosci.2010.05.010)

Guillomot M 1995 Cellular interactions during implantation in domestic ruminants. Journal of Reproduction and Fertility: Supplement 49 39-51.

Guillomot M, Michel C, Gaye P, Charlier N, Trojan J \& Martal J 1990 Cellular localization of an embryonic interferon, ovine trophoblastin and its mRNA in sheep embryos during early pregnancy. Biology of the Cell 68 205-211. (doi:10.1016/0248-4900(90)90309-Q)

Guillomot M, Flechon JE \& Leroy F 1993 Blastocyst development and implantation. In Reproduction in Mammals and Man, pp 387-411. Paris: Ellipses.

Han H, Austin KJ, Rempel LA \& Hansen TR 2006 Low blood ISG15 mRNA and progesterone levels are predictive of non-pregnant dairy cows. Journal of Endocrinology 191 505-512. (doi:10.1677/joe.1.07015)

Hansel W \& Blair RM 1996 Bovine corpus luteum: a historic overview and implications for future research. Theriogenology 45 1267-1294. (doi:10.1016/0093-691X(96)00098-2)

Hansen TR \& Galligan D 2007 Strategies for early diagnosis of open/pregnant cows: current status, economical Implications. Proceedings of Dairy Cattle Reproduction Council November 2-3, Denver Colorado, 93-107.

Hansen TR \& Rueda B 1991 Identifying early pregnancy in cattle. Cow Country January 16-17. Accessed from www.drcouncil.org

Hansen TR, Kazemi M, Keisler DH, Malathy PV, Imakawa K \& Roberts RM 1989 Complex binding of the embryonic interferon, ovine trophoblast protein-1, to endometrial receptors. Journal of Interferon Research 9 215-225. (doi:10.1089/jir.1989.9.215)

Hansen TR, Austin KJ, Perry DJ, Pru JK, Teixeira MG \& Johnson GA 1999 Mechanism of action of interferon-tau in the uterus during early pregnancy. Journal of Reproduction and Fertility: Supplement $\mathbf{5 4}$ 329-339.

Hansen TR, Henkes LK, Ashley RL, Bott RC, Antoniazzi AQ \& Han H 2010 Endocrine actions of interferon-tau in ruminants. Society of Reproduction and Fertility Supplement 67 325-340.

Hansen TR, Smirnova NP, Webb BT, Bielefeldt-Ohmann H, Sacco RE \& Van Campen H 2015 Innate and adaptive immune responses to in utero infection with bovine viral diarrhea virus. Animal Health Research Reviews 16 15-26. (doi:10.1017/S1466252315000122)

Hansen TR, Bott R, Romero J, Antoniazzi A \& Davis JS 2017 Corpus luteum and early pregnancy in ruminants. In The Life Cycle of the Corpus Luteum, pp 205-225.

Hasler JF, Henderson WB, Hurtgen PJ, Jin ZQ, McCauley AD, Mower SA, Neely B, Shuey LS, Stokes JE \& Trimmer SA 1995 Production, freezing and transfer of bovine IVF embryos and subsequent calving results. Theriogenology 43 141-152. (doi:10.1016/0093691X(94)00020-U)

Heyman Y, Camous S, Fevre J, Meziou W \& Martal J 1984 Maintenance of the corpus luteum after uterine transfer of trophoblastic vesicles to cyclic cows and ewes. Journal of Reproduction and Fertility 70 533-540. (doi:10.1530/jrf.0.0700533)

Hixon JE \& Flint AP 1987 Effects of a luteolytic dose of oestradiol benzoate on uterine oxytocin receptor concentrations, phosphoinositide turnover and prostaglandin F- 2 alpha secretion in sheep. Journal of Reproduction and Fertility 79 457-467. (doi:10.1530/jrf.0.0790457)

Ing NH, Francis H, McDonnell JJ, Amann JF \& Roberts RM 1989 Progesterone induction of the uterine milk proteins: major secretory proteins of sheep endometrium. Biology of Reproduction 41 643-654. (doi:10.1095/biolreprod41.4.643)

Inskeep EK, Smutny WJ, Butcher RL \& Pexton JE 1975 Effects of intrafollicular injections of prostaglandins in non-pregnant and pregnant ewes. Journal of Animal Science 41 1098-1104. (doi:10.2527/jas1975.4141098x)

Johnson GA, Austin KJ, Collins AM, Murdoch WJ \& Hansen TR 1999a Endometrial ISG17 mRNA and a related mRNA are induced by interferontau and localized to glandular epithelial and stromal cells from pregnant cows. Endocrine 10 243-252. (doi:10.1007/BF02738623)

Johnson GA, Spencer TE, Hansen TR, Austin KJ, Burghardt RC \& Bazer FW $1999 b$ Expression of the interferon tau inducible ubiquitin crossreactive protein in the ovine uterus. Biology of Reproduction $\mathbf{6 1}$ 312-318. (doi:10.1095/biolreprod61.1.312)

Johnson GA, Spencer TE, Burghardt RC, Joyce MM \& Bazer FW 2000a Interferon-tau and progesterone regulate ubiquitin cross-reactive protein expression in the ovine uterus. Biology of Reproduction 62 622-627. (doi:10.1095/biolreprod62.3.622)

Johnson GA, Spencer TE, Burghardt RC, Taylor KM, Gray CA \& Bazer FW $2000 b$ Progesterone modulation of osteopontin gene expression in the ovine uterus. Biology of Reproduction 62 1315-1321. (doi:10.1095/ biolreprod62.5.1315)

Johnson GA, Stewart MD, Gray CA, Choi Y, Burghardt RC, Yu-Lee LY, Bazer FW \& Spencer TE 2001 Effects of the estrous cycle, pregnancy, and interferon tau on $2^{\prime}, 5^{\prime}$-oligoadenylate synthetase expression in the ovine uterus. Biology of Reproduction 64 1392-1399. (doi:10.1095/ biolreprod64.5.1392)

Kazemi M, Malathy PV, Keisler DH \& Roberts RM 1988 Ovine trophoblast protein-1 and bovine trophoblast protein-1 are present as specific components of uterine flushings of pregnant ewes and cows. Biology of Reproduction 39 457-463. (doi:10.1095/biolreprod39.2.457)

Kim S, Choi Y, Bazer FW \& Spencer TE 2003a Identification of genes in the ovine endometrium regulated by interferon tau independent of signal transducer and activator of transcription 1. Endocrinology 144 5203-5214. (doi:10.1210/en.2003-0665)

Kim S, Choi Y, Spencer TE \& Bazer FW 2003b Effects of the estrous cycle, pregnancy and interferon tau on expression of cyclooxygenase two (COX2) in ovine endometrium. Reproductive Biology and Endocrinology 158. (doi:10.1186/1477-7827-1-58)

Knickerbocker JJ, Thatcher WW, Bazer FW, Barron DH \& Roberts RM 1986a Inhibition of uterine prostaglandin-F2 alpha production by bovine conceptus secretory proteins. Prostaglandins 31 777-793. (doi:10.1016/0090-6980(86)90180-2)

Knickerbocker JJ, Thatcher WW, Bazer FW, Drost M, Barron DH, Fincher KB \& Roberts RM 1986 b Proteins secreted by day-16 to -18 bovine conceptuses extend corpus luteum function in cows. Journal of Reproduction and Fertility 77 381-391. (doi:10.1530/jrf.0.0770381)

Kose M, Kaya MS, Aydilek N, Kucukaslan I, Bayril T, Bademkiran S, Kiyma Z, Ozyurtlu N, Kayis SA, Guzeloglu A et al. 2016 Expression profile of interferon tau-stimulated genes in ovine peripheral blood leukocytes during embryonic death. Theriogenology 85 1161-1166. (doi:10.1016/j. theriogenology.2015.11.032)

Kotwica J, Skarzynski D, Bogacki M, Melin P \& Starostka B 1997 The use of an oxytocin antagonist to study the function of ovarian oxytocin during luteolysis in cattle. Theriogenology 48 1287-1299. (doi:10.1016/ S0093-691X(97)00371-3)

Lamming GE, Wathes DC, Flint AP, Payne JH, Stevenson KR \& Vallet JL 1995 Local action of trophoblast interferons in suppression of the development of oxytocin and oestradiol receptors in ovine endometrium. Journal of Reproduction and Fertility 105 165-175. (doi:10.1530/jrf.0.1050165)

Lee J, Banu SK, Nithy TK, Stanley JA \& Arosh JA 2012a Early pregnancy induced expression of prostaglandin E2 receptors EP2 and EP4 in the ovine endometrium and regulated by interferon tau through multiple cell signaling pathways. Molecular and Cellular Endocrinology $\mathbf{3 4 8}$ 211-223. (doi:10.1016/j.mce.2011.08.020) 
Lee J, McCracken JA, Stanley JA, Nithy TK, Banu SK \& Arosh JA 2012b Intraluteal prostaglandin biosynthesis and signaling are selectively directed towards PGF2alpha during luteolysis but towards PGE2 during the establishment of pregnancy in sheep. Biology of Reproduction 8797. (doi:10.1095/biolreprod.112.100438)

Li J \& Roberts RM 1994 Structure-function relationships in the interferontau (IFN-tau). Changes in receptor binding and in antiviral and antiproliferative activities resulting from site-directed mutagenesis performed near the carboxyl terminus. Journal of Biological Chemistry $26924826-24833$.

Lonergan P \& Forde N 2014 Maternal-embryo interaction leading up to the initiation of implantation of pregnancy in cattle. Animal 8 (Supplement 1) 64-69. (doi:10.1017/S1751731114000470)

Lonergan P, Forde N \& Spencer T 2015 Role of progesterone in embryo development in cattle. Reproduction, Fertility and Development 28 66-74. (doi:10.1071/RD15326)

Maddox-Hyttell P, Gjorret JO, Vajta G, Alexopoulos NI, Lewis I, Trounson A, Viuff D, Laurincik J, Muller M, Tveden-Nyborg P et al. 2003 Morphological assessment of preimplantation embryo quality in cattle. Reproduction Supplement 61 103-116.

Magata F, Shirasuna K, Struve K, Herzog K, Shimizu T, Bollwein H \& Miyamoto A 2012 Gene expressions in the persistent corpus luteum of postpartum dairy cows: distinct profiles from the corpora lutea of the estrous cycle and pregnancy. Journal of Reproduction and Development 58 445-452. (doi:10.1262/jrd.2011-049)

Mansouri-Attia N, Aubert J, Reinaud P, Giraud-Delville C, Taghouti G, Galio L, Everts RE, Degrelle S, Richard C, Hue I et al. 2009 Gene expression profiles of bovine caruncular and intercaruncular endometrium at implantation. Physiological Genomics 39 14-27. (doi:10.1152/physiolgenomics.90404.2008)

Mapletoft RJ, Del Campo MR \& Ginther OJ 1976a Local venoarterial pathway for uterine-induced luteolysis in cows. Proceedings of the Society for Experimental Biology and Medicine 153 289-294. (doi:10.3181/00379727-153-39530)

Mapletoft RJ, Lapin DR \& Ginther OJ $1976 b$ The ovarian artery as the final component of the local luteotropic pathway between a gravid uterine horn and ovary in ewes. Biology of Reproduction 15 414-421. (doi:10.1095/biolreprod15.3.414)

Martin C, Pessemesse L, de la Llosa-Hermier MP, Martal J, Djiane J \& Charlier M 2004 Interferon-\{tau\} upregulates prolactin receptor mRNA in the ovine endometrium during the peri-implantation period. Reproduction 128 99-105. (doi:10.1530/rep.1.00158)

Matsuyama S, Kojima T, Kato S \& Kimura K 2012 Relationship between quantity of IFNT estimated by IFN-stimulated gene expression in peripheral blood mononuclear cells and bovine embryonic mortality after AI or ET. Reproductive Biology and Endocrinology 1021. (doi:10.1186/1477-7827-10-21)

McCracken J, Schramm W \& Okulicz WC 1984 Hormone receptor control of pulsatile secretion of PGF-2Alpha from the ovine uterus during luteolysis and its abrogation in early pregnancy. Animal Reproduction Science 7 31-55. (doi:10.1016/0378-4320(84)90027-7)

McCracken JA, Custer EE \& Lamsa JC 1999 Luteolysis: a neuroendocrinemediated event. Physiological Reviews 79 263-323.

Meyer MD, Hansen PJ, Thatcher WW, Drost M, Badinga L, Roberts RM, Li J, Ott TL \& Bazer FW 1995 Extension of corpus luteum lifespan and reduction of uterine secretion of prostaglandin F2 alpha of cows in response to recombinant interferon-tau. Journal of Dairy Science 78 1921-1931. (doi:10.3168/jds.S0022-0302(95)76817-5)

Meyerholz MM, Mense K, Knaack H, Sandra O \& Schmicke M 2016 Pregnancy-induced ISG-15 and MX-1 gene expression is detected in the liver of holstein-friesian heifers during late peri-implantation period. Reproduction in Domestic Animals 51 175-177. (doi:10.1111/ rda.12638)

Miyamoto A, Shirasuna K, Haneda S, Shimizu T \& Matsui M 2014 Cell biology symposium: perspectives: possible roles of polymorphonuclear neutrophils in angiogenesis and lymphangiogenesis in the corpus luteum during development and early pregnancy in ruminants. Journal of Animal Science 921834 1839. (doi:10.2527/jas.2013-7332)

Monteiro PL Jr, Ribeiro ES, Maciel RP, Dias AL, Sole E Jr, Lima FS, Bisinotto RS, Thatcher WW, Sartori R \& Santos JE 2014 Effects of supplemental progesterone after artificial insemination on expression of interferon-stimulated genes and fertility in dairy cows. Journal of Dairy Science 97 4907-4921. (doi:10.3168/jds.2013-7802)

Moor RM \& Rowson LE 1966a The corpus luteum of the sheep: functional relationship between the embryo and the corpus luteum. Journal of Endocrinology 34 233-239. (doi:10.1677/joe.0.0340233)

Moor RM \& Rowson LE 1966 bocal maintenance of the corpus luteum in sheep with embryos transferred to various isolated portions of the uterus. Journal of Reproduction and Fertility 12 539-550. (doi:10.1530/ jrf.0.0120539)

Moor RM, Rowson LE, Hay MF \& Caldwell BV 1969 The corpus luteum of the sheep: effect of the conceptus on luteal function at several stages during pregnancy. Journal of Endocrinology 43 301-307. (doi:10.1677/ joe.0.0430301)

Morgan GL, Geisert RD, McCann JP, Bazer FW, Ott TL, Mirando MA \& Stewart M 1993 Failure of luteolysis and extension of the interoestrous interval in sheep treated with the progesterone antagonist mifepristone (RU 486). Journal of Reproduction and Fertility 98 451-457. (doi:10.1530/jrf.0.0980451)

Nagaoka K, Nojima H, Watanabe F, Chang KT, Christenson RK, Sakai S \& Imakawa K 2003a Regulation of blastocyst migration, apposition, and initial adhesion by a chemokine, interferon gamma-inducible protein 10 kDa (IP-10), during early gestation. Journal of Biological Chemistry 278 29048-29056. (doi:10.1074/jbc.M300470200)

Nagaoka K, Sakai A, Nojima H, Suda Y, Yokomizo Y, Imakawa K, Sakai S \& Christenson RK 2003 b A chemokine, interferon (IFN)-gamma-inducible protein $10 \mathrm{kDa}$, is stimulated by IFN-tau and recruits immune cells in the ovine endometrium. Biology of Reproduction 68 1413-1421. (doi:10.1095/biolreprod.102.008912)

Nakamura K, Kusama K, Bai R, Sakurai T, Isuzugawa K, Godkin JD, Suda Y \& Imakawa K 2016 Induction of IFNT-stimulated genes by conceptus-derived exosomes during the attachment period. PLOS ONE 11 e0158278. (doi:10.1371/journal.pone.0158278)

Newton GR, Ott TL, Woldesenbet S, Shelton AM \& Bazer FW 1996 Biochemical and immunological properties of related small ruminant trophoblast interferons. Theriogenology 46 703-716. (doi:10.1016/0093691X(96)00222-1)

Nitta A, Shirasuna K, Haneda S, Matsui M, Shimizu T, Matsuyama S, Kimura K, Bollwein H \& Miyamoto A 2011 Possible involvement of IFNT in lymphangiogenesis in the corpus luteum during the maternal recognition period in the cow. Reproduction 142 879-892. (doi:10.1530/ REP-11-0157)

Noel S, Herman A, Johnson GA, Gray CA, Stewart MD, Bazer FW, Gertler A \& Spencer TE 2003 Ovine placental lactogen specifically binds to endometrial glands of the ovine uterus. Biology of Reproduction 68 772-780. (doi:10.1095/biolreprod.102.009183)

Okumu LA, Forde N, Fahey AG, Fitzpatrick E, Roche JF, Crowe MA \& Lonergan P 2010 The effect of elevated progesterone and pregnancy status on mRNA expression and localisation of progesterone and oestrogen receptors in the bovine uterus. Reproduction 140 143-153. (doi:10.1530/REP-10-0113)

Oliveira JF, Henkes LE, Ashley RL, Purcell SH, Smirnova NP, Veeramachaneni DN, Anthony RV \& Hansen TR 2008 Expression of interferon (IFN)-stimulated genes in extrauterine tissues during early pregnancy in sheep is the consequence of endocrine IFN-tau release from the uterine vein. Endocrinology 149 1252-1259. (doi:10.1210/ en.2007-0863)

Ott T, Van Heeke G, Hostetler C, Schalue TK, Olmsted JJ, Johnson HM \& Bazer F 1993 Intrauterine injection of recombinant ovine interferon-tau extends the interestrous interval in sheep. Theriogenology 40 757-769. (doi:10.1016/0093-691X(93)90211-M)

Ott TL, Yin J, Wiley AA, Kim HT, Gerami-Naini B, Spencer TE, Bartol FF, Burghardt RC \& Bazer FW 1998 Effects of the estrous cycle and early pregnancy on uterine expression of $\mathrm{Mx}$ protein in sheep (Ovis aries). Biology of Reproduction 59 784-794. (doi:10.1095/ biolreprod59.4.784)

Platanias LC 2005 Mechanisms of type-I- and type-Il-interferon-mediated signalling. Nature Reviews Immunology 5 375-386. (doi:10.1038/ nri1604)

Pontzer CH, Torres BA, Vallet JL, Bazer FW \& Johnson HM 1988 Antiviral activity of the pregnancy recognition hormone ovine trophoblast protein-1. Biochemical and Biophysical Research Communications 152 801-807. (doi:10.1016/S0006-291X(88)80109-8) 
Pratt BR, Butcher RL \& Inskeep EK 1977 Antiluteolytic effect of the conceptus and of PGE2 in ewes. Journal of Animal Science 45 784-791. (doi:10.2527/jas1977.454784x)

Pugliesi G, Miagawa BT, Paiva YN, Franca MR, Silva LA \& Binelli M 2014 Conceptus-induced changes in the gene expression of blood immune cells and the ultrasound-accessed luteal function in beef cattle: how early can we detect pregnancy? Biology of Reproduction 9195. (doi:10.1095/biolreprod.114.121525)

Ribeiro ES, Bruno RG, Farias AM, Hernandez-Rivera JA, Gomes GC, Surjus R, Becker LF, Birt A, Ott TL, Branen JR et al. 2014 Low doses of bovine somatotropin enhance conceptus development and fertility in lactating dairy cows. Biology of Reproduction 90 10. (doi:10.1095/ biolreprod.113.114694)

Ribeiro E, Santos JE \& Thatcher WW 2016 Role of lipids on elongation of the preimplantation conceptus in ruminants. Reproduction 152 R115-R126. (doi:10.1530/REP-16-0104)

Roberts RM, Ealy AD, Alexenko AP, Han CS \& Ezashi T 1999 Trophoblast interferons. Placenta 20 259-264. (doi:10.1053/plac.1998.0381)

Roberts RM, Chen Y, Ezashi T \& Walker AM 2008a Interferons and the maternal-conceptus dialog in mammals. Seminars in Cell and Developmental Biology 19 170-177. (doi:10.1016/j. semcdb.2007.10.007)

Roberts RM, Chen Y, Ezashi T \& Walker AM 2008b Interferons and the maternal-conceptus dialog in mammals. Seminars in Cell and Developmental Biology 19 170-177.

Robinson RS, Mann GE, Lamming GE \& Wathes DC 1999 The effect of pregnancy on the expression of uterine oxytocin, oestrogen and progesterone receptors during early pregnancy in the cow. Journal of Endocrinology 160 21-33. (doi:10.1677/joe.0.1600021)

Romero J, Antoniazzi AQ, Smirnova NP, Webb BT, Yu F, Davis JS \& Hansen TR 2013 Pregnancy-associated genes contribute to antiluteolytic mechanisms in ovine corpus luteum. Physiological Genomics 45 1095-1108. (doi:10.1152/physiolgenomics.00082.2013)

Romero JJ, Antoniazzi AQ, Nett TM, Ashley RL, Webb BT, Smirnova NP, Bott RC, Bruemmer JE, Bazer FW, Anthony RV \& Hansen TR 2015 Temporal release, paracrine and endocrine actions of ovine conceptusderived interferon-tau during early pregnancy. Biology of Reproduction 93 146. (doi:10.1095/biolreprod.115.132860)

Rosenfeld CS, Han CS, Alexenko AP, Spencer TE \& Roberts RM 2002 Expression of interferon receptor subunits, IFNAR1 and IFNAR2, in the ovine uterus. Biology of Reproduction 67 847-853. (doi:10.1095/ biolreprod.102.004267)

Ruiz-Gonzalez I, Xu J, Wang X, Burghardt RC, Dunlap KA \& Bazer FW 2015 Exosomes, endogenous retroviruses and toll-like receptors: pregnancy recognition in ewes. Reproduction 149 281-291. (doi:10.1530/REP14-0538)

Sakumoto R, Hayashi KG, Fujii S, Kanahara H, Hosoe M, Furusawa T \& Kizaki K 2017 Possible roles of CC-and CXC-chemokines in regulating bovine endometrial function during early pregnancy. International Journal of Molecular Sciences 18 E742. (doi:10.3390/ijms18040742)

Satterfield MC, Bazer FW \& Spencer TE 2006 Progesterone regulation of preimplantation conceptus growth and galectin 15 (LGALS15) in the ovine uterus. Biology of Reproduction 75 289-296. (doi:10.1095/ biolreprod.106.052944)

Satterfield MC, Dunlap KA, Hayashi K, Burghardt RC, Spencer TE \& Bazer FW 2007 Tight and adherens junctions in the ovine uterus: differential regulation by pregnancy and progesterone. Endocrinology 148 3922-3931. (doi:10.1210/en.2007-0321)

Schalue-Francis TK, Farin PW, Cross JC, Keisler D \& Roberts RM 1991 Effect of injected bovine interferon-alpha I1 on estrous cycle length and pregnancy success in sheep. Journal of Reproduction and Fertility 91 347-356. (doi:10.1530/jrf.0.0910347)

Schneider WM, Chevillotte MD \& Rice CM 2014 Interferon-stimulated genes: a complex web of host defenses. Annual Review of Immunology 32 513-545. (doi:10.1146/annurev-immunol-032713-120231)

Shirasuna K, Matsumoto H, Matsuyama S, Kimura K, Bollwein H \& Miyamoto A 2015 Possible role of interferon tau on the bovine corpus luteum and neutrophils during the early pregnancy. Reproduction 150 217-225. (doi:10.1530/REP-15-0085)

Silvia WJ \& Niswender GD 1984 Maintenance of the corpus luteum of early pregnancy in the ewe. III. Differences between pregnant and nonpregnant ewes in luteal responsiveness to prostaglandin
F2 alpha. Journal of Animal Science 59 746-753. (doi:10.2527/ jas1984.593746x)

Silvia WJ \& Niswender GD 1986 Maintenance of the corpus luteum of early pregnancy in the ewe. IV. Changes in luteal sensitivity to prostaglandin F2 alpha throughout early pregnancy. Journal of Animal Science 63 1201-1207. (doi:10.2527/jas1986.6341201x)

Silva PJ, Juengel JL, Rollyson MK \& Niswender GD 2000 Prostaglandin metabolism in the ovine corpus luteum: catabolism of prostaglandin $\mathrm{F}$ (2alpha) (PGF(2alpha)) coincides with resistance of the corpus luteum to PGF(2alpha). Biology of Reproduction 63 1229-1236. (doi:10.1095/ biolreprod63.5.1229)

Simmons RM, Satterfield MC, Welsh TH Jr, Bazer FW \& Spencer TE 2010 HSD11B1, HSD11B2, PTGS2, and NR3C1 expression in the peri-implantation ovine uterus: effects of pregnancy, progesterone, and interferon tau. Biology of Reproduction 82 35-43. (doi:10.1095/ biolreprod.109.079608)

Sinedino LD, Honda PM, Souza LR, Lock AL, Boland MP, Staples CR, Thatcher WW \& Santos JE 2017 Effects of supplementation with docosahexaenoic acid on reproduction of dairy cows. Reproduction 153 707-723. (doi:10.1530/REP-16-0642)

Song G, Spencer TE \& Bazer FW 2005 Cathepsins in the ovine uterus: regulation by pregnancy, progesterone, and interferon tau. Endocrinology 146 4825-4833. (doi:10.1210/en.2005-0768)

Song G, Bazer FW, Wagner GF \& Spencer TE 2006a Stanniocalcin (STC) in the endometrial glands of the ovine uterus: regulation by progesterone and placental hormones. Biology of Reproduction 74 913-922. (doi:10.1095/biolreprod.106.050807)

Song G, Spencer TE \& Bazer FW 2006b Progesterone and interferon tau regulate cystatin $C$ (CST3) in the endometrium. Endocrinology $\mathbf{1 4 7}$ 3478-3483.

Song G, Bazer FW \& Spencer TE 2007 Pregnancy and interferon tau regulate RSAD2 and IFIH1 expression in the ovine uterus. Reproduction 133 285-295. (doi:10.1530/REP-06-0092)

Spencer TE \& Bazer FW 1995 Temporal and spatial alterations in uterine estrogen receptor and progesterone receptor gene expression during the estrous cycle and early pregnancy in the ewe. Biology of Reproduction 53 1527-1543. (doi:10.1095/biolreprod53.6.1527)

Spencer TE \& Bazer FW 1996 Ovine interferon tau suppresses transcription of the estrogen receptor and oxytocin receptor genes in the ovine endometrium. Endocrinology 137 1144-1147. (doi:10.1210/ endo.137.3.8603586)

Spencer TE \& Bazer FW 2002 Biology of progesterone action during pregnancy recognition and maintenance of pregnancy. Frontiers in Bioscience 7 d1879-d1898. (doi:10.2741/spencer)

Spencer TE \& Hansen TR 2015 Implantation and establishment of pregnancy in ruminants. Advances in Anatomy, Embryology and Cell Biology 216 105-135.

Spencer TE, Becker WC, George P, Mirando MA, Ogle TF \& Bazer FW 1995a Ovine interferon-tau inhibits estrogen receptor up-regulation and estrogen-induced luteolysis in cyclic ewes. Endocrinology 136 4932-4944. (doi:10.1210/endo.136.11.7588227)

Spencer TE, Becker WC, George P, Mirando MA, Ogle TF \& Bazer FW $1995 b$ Ovine interferon-tau regulates expression of endometrial receptors for estrogen and oxytocin but not progesterone. Biology of Reproduction 53 732-745. (doi:10.1095/biolreprod53.3.732)

Spencer TE, Ing NH, Ott TL, Mayes JS, Becker WC, Watson GH, Mirando MA \& Brazer FW 1995C Intrauterine injection of ovine interferontau alters oestrogen receptor and oxytocin receptor expression in the endometrium of cyclic ewes. Journal of Molecular Endocrinology 15 203-220. (doi:10.1677/jme.0.0150203)

Spencer TE, Mirando MA, Mayes JS, Watson GH, Ott TL \& Bazer FW 1996a Effects of interferon-tau and progesterone on oestrogen-stimulated expression of receptors for oestrogen, progesterone and oxytocin in the endometrium of ovariectomized ewes. Reproduction, Fertility and Development 8 843-853. (doi:10.1071/RD9960843)

Spencer TE, Ott TL \& Bazer FW $1996 b$ tau-interferon: pregnancy recognition signal in ruminants. Proceedings of the Society for Experimental Biology and Medicine 213 215-229. (doi:10.3181/00379727-213-44053)

Spencer TE, Ott TL \& Bazer FW 1998 Expression of interferon regulatory factors one and two in the ovine endometrium: effects of pregnancy and ovine interferon tau. Biology of Reproduction 58 1154-1162. (doi:10.1095/biolreprod58.5.1154) 
Spencer TE, Bartol FF, Bazer FW, Johnson GA \& Joyce MM 1999a Identification and characterization of glycosylation-dependent cell adhesion molecule 1-like protein expression in the ovine uterus. Biology of Reproduction 60 241-250. (doi:10.1095/biolreprod60.2.241)

Spencer TE, Gray A, Johnson GA, Taylor KM, Gertler A, Gootwine E, Ott TL \& Bazer FW 1999b Effects of recombinant ovine interferon tau, placental lactogen, and growth hormone on the ovine uterus. Biology of Reproduction 61 1409-1418. (doi:10.1095/biolreprod61.6.1409)

SpencerTE, Burghardt RC, Johnson GA \& Bazer FW 2004a Conceptus signals for establishment and maintenance of pregnancy. Animal Reproduction Science 82-83 537-550. (doi:10.1016/j.anireprosci.2004.04.014)

Spencer TE, Johnson GA, Bazer FW \& Burghardt RC $2004 \mathrm{~b}$ Implantation mechanisms: insights from the sheep. Reproduction 128 657-668. (doi:10.1530/rep.1.00398)

Spencer TE, Johnson GA, Burghardt RC \& Bazer FW 2004C Progesterone and placental hormone actions on the uterus: insights from domestic animals. Biology of Reproduction 71 2-10. (doi:10.1095/ biolreprod.103.024133)

Spencer TE, Johnson GA, Bazer FW \& Burghardt RC 2007 Fetal-maternal interactions during the establishment of pregnancy in ruminants. Society of Reproduction and Fertility Supplement 64 379-396.

Spencer TE, Sandra O \& Wolf E 2008 Genes involved in conceptusendometrial interactions in ruminants: insights from reductionism and thoughts on holistic approaches. Reproduction 135 165-179. (doi:10.1530/REP-07-0327)

Spencer TE, Forde N, Dorniak P, Hansen TR, Romero JJ \& Lonergan P 2013 Conceptus-derived prostaglandins regulate gene expression in the endometrium prior to pregnancy recognition in ruminants. Reproduction 146 377-387. (doi:10.1530/REP-13-0165)

Spencer TE, Forde N \& Lonergan P 2016 The role of progesterone and conceptus-derived factors in uterine biology during early pregnancy in ruminants. Journal of Dairy Science 99 5941-5950. (doi:10.3168/ jds.2015-10070)

Stark GR, Kerr IM, Williams BR, Silverman RH \& Schreiber RD 1998 How cells respond to interferons. Annual Review of Biochemistry 67 227-264. (doi:10.1146/annurev.biochem.67.1.227)

Stevenson JL, Dalton JC, Ott TL, Racicot KE \& Chebel RC 2007 Correlation between reproductive status and steady-state messenger ribonucleic acid levels of the Myxovirus resistance gene, $M X 2$, in peripheral blood leukocytes of dairy heifers. Journal of Animal Science 85 2163-2172. (doi:10.2527/jas.2007-0014)

Stewart MD, Johnson GA, Gray CA, Burghardt RC, Schuler LA, Joyce MM, Bazer FW \& Spencer TE 2000 Prolactin receptor and uterine milk protein expression in the ovine endometrium during the estrous cycle and pregnancy. Biology of Reproduction 62 1779-1789. (doi:10.1095/ biolreprod62.6.1779)

Takahashi H, Takahashi M, Nagaya H, Hirako M, Sawai K, Minamihashi A, Inumaru S, Yokomizo Y, Geshi M, Okano A et al. 2005 Establishment of a specific radioimmunoassay for bovine interferon tau. Theriogenology 63 1050-1060. (doi:10.1016/j.theriogenology.2004.05.019)

Taniguchi T, Ogasawara K, Takaoka A \& Tanaka N 2001 IRF family of transcription factors as regulators of host defense. Annual Review of Immunology 19 623-655. (doi:10.1146/annurev.immunol.19.1.623)

Telgmann R, Bathgate RA, Jaeger S, Tillmann G \& Ivell R 2003 Transcriptional regulation of the bovine oxytocin receptor gene. Biology of Reproduction 68 1015-1026. (doi:10.1095/ biolreprod.102.008961)

Thatcher WW, Bazer FW, Sharp DC \& Roberts RM 1986 Interrelationships between uterus and conceptus to maintain corpus luteum function in early pregnancy: sheep, cattle, pigs and horses. Journal of Animal Science 62 (Supplement 2) 25-46.

Thatcher WW, Hansen PJ, Gross TS, Helmer SD, Plante C \& Bazer FW 1989 Antiluteolytic effects of bovine trophoblast protein-1. Journal of Reproduction and Fertility: Supplement 37 91-99.

Thatcher WW, Guzeloglu A, Mattos R, Binelli M, Hansen TR \& Pru JK 2001 Uterine-conceptus interactions and reproductive failure in cattle. Theriogenology 56 1435-1450. (doi:10.1016/S0093-691X(01)00645-8)

Vallet JL \& Bazer FW 1989 Effect of ovine trophoblast protein-1, oestrogen and progesterone on oxytocin-induced phosphatidylinositol turnover in endometrium of sheep. Journal of Reproduction and Fertility 87 755-761. (doi:10.1530/jrf.0.0870755)
Vallet JL, Bazer FW, Ashworth CJ, Johnson HM \& Pontzer CH 1988a Development of a radioimmunoassay for ovine trophoblast protein-1, the antiluteolytic protein from the sheep conceptus. Journal of Endocrinology 117 R5-R8. (doi:10.1677/joe.0.117R005)

Vallet JL, Bazer FW, Fliss MF \& Thatcher WW 1988b Effect of ovine conceptus secretory proteins and purified ovine trophoblast protein-1 on interoestrous interval and plasma concentrations of prostaglandins F-2 alpha and E and of 13,14-dihydro- 15-keto prostaglandin F-2 alpha in cyclic ewes. Journal of Reproduction and Fertility 84 493-504. (doi:10.1530/jrf.0.0840493)

Wales RG \& Cuneo CL 1989 Morphology and chemical analysis of the sheep conceptus from the 13th to the 19th day of pregnancy. Reproduction, Fertility and Development 1 31-39. (doi:10.1071/RD9890031)

Wang J, Guillomot M \& Hue I 2009 Cellular organization of the trophoblastic epithelium in elongating conceptuses of ruminants. Comptes Rendus Biologies 332 986-997. (doi:10.1016/j.crvi.2009.09.004)

Wang XL, Wang K, Han GC \& Zeng SM 2013 A potential autocrine role for interferon tau in ovine trophectoderm. Reproduction in Domestic Animals 48 819-825. (doi:10.1111/rda.12169)

Wang X, Frank JW, Little DR, Dunlap KA, Satterfield MC, Burghardt RC, Hansen TR, Wu G \& Bazer FW 2014 Functional role of arginine during the peri-implantation period of pregnancy. I. Consequences of loss of function of arginine transporter SLC7A1 mRNA in ovine conceptus trophectoderm. FASEB Journal 28 2852-2863. (doi:10.1096/fj.13248757)

Wathes DC \& Hamon M 1993 Localization of oestradiol, progesterone and oxytocin receptors in the uterus during the oestrous cycle and early pregnancy of the ewe. Journal of Endocrinology 138 479-492. (doi:10.1677/joe.0.1380479)

Wathes DC \& Lamming GE 1995 The oxytocin receptor, luteolysis and the maintenance of pregnancy. Journal of Reproduction and Fertility: Supplement 49 53-67.

Whitley JC, Shulkes A, Salamonsen LA, Vogiagis D, Familari M \& Giraud AS 1998 Temporal expression and cellular localization of a gastrinreleasing peptide-related gene in ovine uterus during the oestrous cycle and pregnancy. Journal of Endocrinology 157 139-148. (doi:10.1677/ joe.0.1570139)

Wijma R, Stangaferro ML, Kamat MM, Vasudevan S, Ott TL \& Giordano JO 2016 Embryo mortality around the period of maintenance of the corpus luteum causes alterations to the ovarian function of lactating dairy cows. Biology of Reproduction 95 112. (doi:10.1095/ biolreprod.116.142075)

Wilson L Jr, Butcher RL \& Inskeep EK 1972 Prostaglandin F2alpha in the uterus of ewes during early pregnancy. Prostaglandins 1 479-482. (doi:10.1016/0090-6980(72)90017-2)

Wiltbank MC, Baez GM, Garcia-Guerra A, Toledo MZ, Monteiro PL, Melo LF, Ochoa JC, Santos JE \& Sartori R 2016 Pivotal periods for pregnancy loss during the first trimester of gestation in lactating dairy cows. Theriogenology 86 239-253. (doi:10.1016/j. theriogenology.2016.04.037)

Woody CO, First NL \& Pope AL 1967 Effect of exogenous progesterone on estrous cycle length. Journal of Animal Science 26 139-141. (doi:10.2527/jas1967.261139x)

Yang L, Wang XL, Wan PC, Zhang LY, Wu Y, Tang DW \& Zeng SM 2010 Up-regulation of expression of interferon-stimulated gene 15 in the bovine corpus luteum during early pregnancy. Journal of Dairy Science 93 1000-1011. (doi:10.3168/jds.2009-2529)

Yankey SJ, Hicks BA, Carnahan KG, Assiri AM, Sinor SJ, Kodali K, Stellflug JN \& Ott TL 2001 Expression of the antiviral protein Mx in peripheral blood mononuclear cells of pregnant and bred, nonpregnant ewes. Journal of Endocrinology 170 R7-R11. (doi:10.1677/ joe.0.170R007)

Received 24 May 2017

First decision 8 August 2017

Revised manuscript received 18 August 2017

Accepted 4 September 2017 